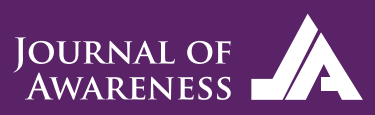

$\left(\begin{array}{l}0 \\ 0\end{array}\right)$
Journal of Awareness

Volume / Cilt: 6, Issue / Sayl:4, 2021, pp. 247-267

E-ISSN: 2149-6544

https://journals.gen.tr/joa

DOI: https://doi.org/10.26809/joa.6.4.06
Received / Geliș: 21.09.2021

Accepted / Kabul: 27.10.2021

\title{
Covid-19 salgını sürecinde yüksek lisans öğrencilerinin gözünden uzaktan eğitim*
}

\section{Distance education through the eyes of postgraduate students during the covid-19 epidemic}

\begin{abstract}
Esen Yıldırım $^{1}$ (D) Gülen Arıkan Kokkaya ${ }^{1}$
1 Prof. Dr., Marmara Üniversitesi, İktisat Fakültesi, Ekonometri Bölümü; İstanbul,Türkiye, e-mail: eyildirim@marmara.edu.tr

2 Arş. Gör., Marmara Üniversitesi, İktisat Fakültesi, Ekonometri Bölümü; İstanbul,Türkiye, e-mail: gulen.arikan@marmara.edu.tr
\end{abstract}

Öz

Bu çalışmada, yüksek lisans öğrencilerinin COVID-19 salgını sürecindeki uzaktan eğitim deneyimleri ele alınmıştır. Çalışma kapsamında, 2020-2021 akademik yılında Marmara Üniversitesi'nde bir yüksek lisans programına kaydolan öğrencilere online anket uygulanmış; veri seti 501 öğrenciden elde edilen bilgilerle derlenmiştir. Örneklemde yer alan öğrenciler; 23-56 yaş grubunda, \%59'u erkek, \%24'ü evli olup ve bir işte çalışanların oranı \%66'dır. Öğrencilerin \%71'i sosyal bilimler, \%19'u fen bilimleri, \% 8'i sağlık bilimleri ve 11 öğrenci de güzel sanatlar alanlarındaki programlara kayıtlı olup; \%74'ü tezli, \%26'sı tezsiz bir yüksek lisans programında eğitim görmektedir.

Çalışma kapsamında, öğrencilerin COVID-19 salgını dönemindeki uzaktan eğitime dair görüşleri ile demografik özellikleri, eğitim gördükleri alan (sosyal, fen, sağlık bilimleri ve güzel sanatlar) ve program türü (tezli, tezsiz) arasındaki ilişki yapısı araştırılmış; salgın sonrası döneme ilişkin eğitim biçimi tercihleri incelenmiştir.

Salgın sürecinin özellikle tezsiz yüksek lisans yapan öğrenciler tarafından bir eğitim fırsatı olarak görüldüğü anlaşılmaktadır. Yüksek lisans programının ilgili olduğu alan yönünden bakıldığında, uzaktan eğitim uygulanacağı için yüksek lisans yapma kararı alanların ağırlığı, fen bilimleri alanında en yüksek düzeyde gözlemlenmiştir. Yüksek lisans öğrencilerinin uzaktan eğitim deneyimlerindeki farklılıklarda cinsiyet etkili değilken; medeni durum, bir işte çalışma durumu ve yaş değişkenleri etkili bulunmuştur. Uzaktan eğitimin yüksek lisans öğrencileri tarafından çok çabuk benimsendiği ve salgın ortadan kalktıktan sonraki dönemde de yüksek lisans düzeyinde talep gören bir eğitim biçimi olacağı anlaşılmıştır.

Anahtar kelimeler: COVID-19, Uzaktan eğitim, Üniversite, Yüksek lisans, Lisansüstü eğitim.

‘Bu çalışma 8.9.2021 tarihinde 21. Uluslararası Ekonometri, Yöneylem Araştırması ve İstatistik Sempozyumu (EYİ2021)'nda sunulmuştur.

Citation/Atıf: YILDIRIM, E. \& ARIKAN KOKKAYA, G., (2021). Covid-19 salgını sürecinde yüksek lisans öğrencilerinin gözünden uzaktan eğitim. Journal of Awareness. 6(4): 247-267, DOI: 10.26809/joa.6.4.06 


\begin{abstract}
In this study, the distance education experiences of graduate students during the COVID19 epidemic were discussed. Within the scope of the study, an online questionnaire was applied to students enrolled in a graduate program at Marmara University in the 2020-2021 academic year and 501 students shared their opinions. The students participating in the survey are in the $23-56$ age group, $59 \%$ are male, $41 \%$ are female, $24 \%$ are married and $66 \%$ work in a job. $71 \%$ of the students are enrolled in social sciences, while 19\% enrolled in science, $8 \%$ enrolled in health sciences and 11 students enrolled in fine arts programs. $74 \%$ of them are studying in a thesis program while $26 \%$ of them are studying in a non-thesis program.

Within the scope of the study, the relationship structure between the students' perspectives on distance education that they experienced during the COVID-19 epidemic; and their demographic characteristics, the field of education (social, science, health sciences and fine arts) and the type of program (with or without thesis) were investigated, and their preferences on type of education for the post-epidemic period were examined.

It is understood that the epidemic period is perceived as an educational opportunity, especially by masters students studies without thesis. In terms of the field of the master's program, since distance education will be applied, the weight of those who decide to do a master's degree is observed at the highest level in the field of science. While gender was not effective on distance education experiences of graduate students; marital status, working status and age variables were found to be effective. It has been understood that distance education has been adopted by graduate students very quickly and at the graduate level, it will be a demanded form of education after the epidemic was over.
\end{abstract}

Keywords: COVID19, Distance Education, Master's degree, University, Postgraduate Education.

\section{Gíriş̧}

Sağlık, ekonomi ve eğitim sektörleri, COVID-19 salgınının doğrudan etkilediği sektörlerin başında gelmektedir. Tüm dünyada ilköğretimden lisansüstü öğretime kadar 1,6 milyar öğrencinin eğitim hayatı, COVID-19 salgınından etkilenmiştir (UNESCO, 2020). Salgının ilanı sonrasında eğitim-öğretim faaliyetleri; televizyon ve radyolardan yapilan yayınlar, internet üzerinden sunulan çevrimiçi dersler, erişime açılan çevrimiçi kaynaklar, ders notları vb. yoluyla sürdürülmeye çalışılmıştır. Zaruri olarak uzaktan eğitime geçişi gerektiren bu süreçte, az gelişmiş ülkelerin birçok bölgesinde öğrenciler için uzaktan eğitime ulaşmak mümkün olmazken; gelişmiş ülkelerde bile önemli sorunlar yaşanmıştır (Tadesse \& Muluye, 2020).

Dünya genelinde olduğu gibi Türkiye'de de COVID-19 salgını öncesinde az sayıda üniversitede kısmi olarak hayata geçirilen uzaktan eğitim, salgın ile birlikte tüm üniversitelerde ani biçimde uygulamaya sokulmuştur. Çoğu üniversite için hazırlıksız yakalanılan ve önemli bir alt yapı gerektiren bu uygulama; öğrenciler, öğretim elemanları ve kurum yöneticileri için hızlı bir değerlendirme, karar alma ve adaptasyon sürecini gerektirmiştir. Uygulamaya konulmasındaki temel amaç, eğitim sürecinin sekteye uğramasını önlemek olan uzaktan eğitim, tüm taraflar açısından bazı dezavantajları da beraberinde getirmiştir.
Akademik alt yapıları, teknoloji tecrübeleri ve iletişim becerileri nedeniyle yüksek lisans (YL) öğrencilerinin, uzaktan eğitime adaptasyonda en az sorun yaşayan öğrenci kitlesi olması beklenir. Buna ek olarak, eğitimin uzaktan uygulanacak olmasının özellikle YL düzeyinde öğrenci tercihlerine etki edeceği de düşünülmüştür. Bu tespitlerden hareketle tarafımızca gerçekleştirilen bu çalışmada, COVID-19 salgını döneminde YL öğrencilerinin gözünden uzaktan eğitim süreci araştırılmıştır.

İzleyen bölümde araştırmanın amacı ve kapsamı detaylı olarak açıklanmış; üçüncü bölümde ise ilgili literatür özetlenmiştir. Dördüncü bölümde, araştırmaya ilişkin metodolojik bilgilere yer verilerek, elde edilen analiz bulguları sunulmuştur. Sonuç bölümünde, öğrencilerin uzaktan eğitime dair görüşleri ve geleceğe dair talepleri değerlendirilmiştir.

\section{ARAŞTIRMANIN AMACI VE KAPSAMI}

Bu çalışmada, salgın döneminin zaruri sonuçlarından biri olarak uzaktan eğitime geçilmesi süreci ve yansımaları, YL öğrencilerinin bakış açısından ele alınmıştır. Araştırmanın amacı, YL öğrencilerinin uzaktan eğitime adaptasyon süreçlerinin araştırılması, karşılaştırmalı olarak yüz yüze ve uzaktan eğitime dair görüşlerinin incelenmesi ve gelecekteki eğitim biçimi tercihlerinin tespit edilmesidir. 
Araştırmanın veri setini oluşturmak üzere, çok çeşitli alanlarda YL eğitimi verilen ve demografik nitelikleri yönünden öğrencilerin heterojen bir yapı sergilediği üniversitelerden Marmara Üniversitesi tercih edilmiştir. Hedef kitle, 2020-2021 Akademik Yılı Bahar Dönemi'nde Marmara Üniversitesi bünyesindeki bir programa kayıt olan YL öğrencileri olarak belirlenmiştir. Araştırma kapsamında, eğitimin uzaktan uygulanacak olmasının öğrenci tercihlerinde etkili olup olmadığı hususu da ele alınacağından, özellikle salgın başladıktan bir yıl sonraki dönemde veri toplanmasına karar verilmiştir.

Çalışma kapsamında, öğrencilerin uzaktan eğitime dair deneyimleri ve görüşleri ile eğitim gördükleri alan (sosyal, fen, sağlık bilimleri ve güzel sanatlar), program türü (tezli, tezsiz) ve cinsiyet, yaş, medeni durum, bir işte çalışma durumu gibi demografik özellikleri arasındaki ilişki yapısı araştırılmıştır.

Bu çerçevede, araştırma kapsamında test edilecek hipotezler aşağıda belirtilmiştir:

- 2020-2021 Bahar Dönemi'nde kayıt olan YL öğrencilerinin YL yapma kararında eğitimin uzaktan yapılıyor olması teşvik edici bir faktör olmuştur.

- Eğitimin uzaktan yapılacak olması, özellikle tezsiz YL yapmayı düşünen öğrenciler üzerinde motive edici olmuştur.

- Eğitimin uzaktan yapılacak olması, özellikle sosyal bilimler alanında YL yapmayı düşünen öğrenciler üzerinde motive edici olmuştur.

- Gençlerde uzaktan eğitime geçiş süreci daha kolay olmuştur.

- Tezli/tezsiz YL programı öğrencisi olmak, salgın dönemindeki uzaktan eğitim süreci deneyiminde fark yaratır.

- YL programının alanı (sosyal, fen, sağlık, güzel sanatlar), öğrencinin salgın dönemindeki uzaktan eğitim süreci deneyiminde fark yaratır.

- Sosyal bilimler alanındaki öğrencilerde uzaktan eğitimden memnuniyet, diğer alanlardan yüksektir.

- Cinsiyet, öğrencinin salgın dönemindeki uzaktan eğitim süreci deneyiminde fark yaratır.
- Medeni durum, öğrencinin salgın dönemindeki uzaktan eğitim süreci deneyiminde fark yaratır.

- Bir işte çalışıp çalışmamak, öğrencinin salgın dönemindeki uzaktan eğitim süreci deneyiminde fark yaratır.

- Ders programı içinde uygulama derslerinin ağırlığı, alınan eğitimden memnuniyeti etkiler.

- Ders programı içinde uygulama derslerinin ağırlığı, öğrenme çıtıları yönünden uzaktan eğitimden tatmin düzeyini etkiler.

- Ders programı içinde uygulama derslerinin ağırlığı, salgın sonrası eğitim biçimi tercihini etkiler.

- Öğrenme çıktıları yönünden uzaktan eğitim hakkındaki görüşler, program türüne göre farklılık gösterir.

- Öğrenme çıktıları yönünden uzaktan eğitim hakkındaki görüşler, eğitim görülen alana göre farklılık gösterir.

- Salgın sonrası dönemde eğitim biçimi tercihi, program türüne bağlı olarak değişir.

- Salgın sonrası dönemde eğitim biçimi tercihi, eğitim görülen alana bağlı olarak değişir.

\section{LITTERATÜR TARAMASI}

COVID-19 salgınının yükseköğretime etkilerinin ele alındığı uluslararası literatür incelendiğinde, çok sayıda çalışmaya ulaşılmıştır. Yapılan çalışmaların bir kısmı öğretim elemanlarının yaşadığı zorlukları ve uzaktan eğitime bakış açılarını ele alırken; bir kısmı konuyu öğrenciler açısından ele almış, uzaktan eğitimin teknolojik nitelikleri, eğitim alan ve veren kesimin uzaktan eğitime yatkınlığı, eşit eğitim hakkı bağlamında uzaktan eğitim gibi konu başlıkları tespit edilmiştir. Öğrencilerin uzaktan eğitim deneyimlerini inceleyen çalışmaların büyük bir kısmı lisans öğrencilerinin görüşlerini ele alırken, lisansüstü düzeyde ya da bölüm bazında (odyometri, psikoloji gibi) inceleme yapılan çalışmalar da mevcuttur.

2021 yılında yapılan Avrupa ülkeleri, Rusya, Türkiye ve Azerbaycan'da “COVID-19 ve uzaktan eğitim" konulu yayınların meta analizini kapsayan çalışmada; bu konuda en çok çalışma yapılan ülkelerin İspanya, Romanya ve Rusya olduğu, verilerin genellikle online anket yolu ile toplandığı, analiz olarak genellikle 
tanımlayıcı istatistiklere yer verildiği, ancak bazı çalışmalarda ki-kare, t testi, ANOVA, yapısal eşitlik modelleri gibi daha ileri tekniklerin de kullanıldı ğı, en sık incelenen boyutların "interaktif öğrenme" ve "uzaktan öğretme stratejileri" olduğu, yükseköğretimin üzerinde daha fazla araştırma yapılan eğitim düzeyi olduğu tespit edilmiştir (Abreu, Costa, \& Paiva, 2021).

Farklı gelir düzeyindeki ülkelerin hükümetleri, okulların kapanması sonrasında eğitimde sürekliliği sağlamak amacıyla farklı uzaktan eğitim yöntemlerini tercih etmişlerdir (Vegas, 2020). Gelir seviyesinin düşük olduğu ülkelerin yaklaşık dörtte biri, öğrencilerine televizyon ve radyo yayını aracılığıyla uzaktan eğitim verebilmiştir. Bu ülkelerde, internete ulaşamayan öğrenciler nedeniyle eğitime katılım oranı düşük düzeyde seyretmiştir (Thomas, 2020). Gelişmiş ülkelerin bir kısmında bile, öğrenciler açısından uzaktan eğitime geçiş sürecinin sıkıntılı olması, az gelişmiş ülkelerdeki uzaktan eğitim stratejilerinin ve etkilerinin araştırılması ihtiyacını doğurmuştur. Bu kapsamda Pakistan'da yapılan bir çalışmada 126 öğrenciden anket yöntemi ile toplanan verilerle ülkenin zorunlu dijital dönüşümü incelenmiştir. Öğrencilerin büyük bir çoğunluğunun teknik ve ekonomik sorunlar nedeniyle internete erişemediği ülkede, uzaktan eğitimin etkin bir eğitim biçimi olmadığı belirtilmiştir. Ayrıca eğitmenle yüz yüze iletişimin olmaması, eğitmenlerin sorulara geri dönüş süresi ve yüz yüze eğitimdeki sosyal etkileşimin uzaktan eğitimde olmaması, yükseköğretim öğrencileri tarafından vurgulanan diğer bazı dezavantajlar arasındadır (Adnan \& Anwar, 2020). Pakistan'da yapılan bir başka çalışmada da salgın öncesi dönemde eğitimin ve akademik kurumların idari faaliyetlerinin tamamen yüz yüze yapılması nedeni ile geçiş sürecinde yaşanan zorluklar ele alınmıştır (Kaur, 2020). Bir diğer çalışmada, Endonezya'da da uzaktan eğitim sürecinin öğrencilerde stres yarattığı ve bunun sanal altyapı sorunlarından kaynaklandığı sonucuna varılmıştır (Jadhav, Bagul, \& Aswale, 2020). Aynı bulgu, Churiyah vd. tarafından yapılan çalışmada da desteklenmiş; ancak bu durumun sebebinin sanal altyapı kaynaklı değil, öğrencilerin bireysel öğrenmedeki başarısızlığı ve eğitmenlerin teknolojik yetersizliği olduğu öne sürülmüştür (Churiyah, Sholikhan, Filianti, \& Sakdiyyah, 2020).

İncelenen çalışmaların bir kısmında ortak çıktı olarak “uzaktan eğitimin öğrenciler arasında ve öğrenciler ile öğretim elemanları arasındaki sosyal etkileşimi sekteye uğratması" yönünden şikayetler göze çarpmaktadır. 2021 yılında Salta vd. tarafından Yunanistan'da yapılan çalışmada, 347 lisans öğrencisi ve bir YL programına devam eden 13 lisansüstü öğrenciden oluşan dört farklı bilim öğrenme topluluğunda, öğrencilerin duygusal bağlılığındaki azalma nedeniyle uzaktan eğitim dezavantajlı bulunmuştur. Yapılan çoklu regresyon analizi sonucunda, öğrencilerin duygusal bağlılığındaki düşüş, büyük ölçüde gelenekselden çevrimiçi öğrenme ortamına geçişte bireyler arası (öğrenci-öğrenci veya öğrenci-eğitmen) etkileşim düzeyindeki düşüşle açıklanmıştır. Bunlara ek olarak, cinsiyetin öğrenme şekline (uzaktan - yüz yüze) göre duygusal bağlılıkta istatistiksel olarak anlamlı olmadığ1 ve öğrencilerin yüz yüze eğitimi tercih ettiği sonucuna varılmıştır (Salta, Paschalidou, \& Tsetseri, 2021).

Kiev Üniversitesi'nde 302 öğrenci ile yürütülen bir diğer çalışmada, uzaktan eğitim sisteminin etkinliği ve teknik erişim olanakları, kullanılan platform ve hizmetlerden yararlanma yönünden Mart - Haziran 2020 dönemleri karşılaştırılmıştır. Araştırmada uzaktan eğitim sürecinde akademik personel ve yöneticiler ile sürekli iletişim kurabilme, yeterli miktarda video konferans ve gerektiğinde yüz yüze görüşebilme imkânının öğrenciler için önemli olduğu tespit edilmiştir. Buna ek olarak; öğrencilerin çoğu sunulan formları ve uzaktan eğitim yöntemlerini verimli bulduğunu; ayr1ca bu tür çalışmalar sırasında üretkenliklerinde belirli bir artış olduğunu ifade etmiştir (Rosinska \& Zhuravska, 2021). Toti ve Alipour tarafından Singapur'da yapılan çalışmada ise, 105 bilgisayar bilimi öğrencisinin uzaktan öğretime geçiş deneyimleri, tanımlayıcı istatistikler ve parametrik olmayan testler ile incelenmiş; 2021 yılında yüksek bilgisayar okuryazarlığının sağladığ1 avantaja rağmen, öğrencilerin özellikle video dersler sırasında soru sorma ve eğitmenlerle etkileşim kurma gibi konularda zorlandıkları anlaşılmıştır. Kişilerin ırkına ve ikamet ettikleri yere göre uzaktan eğitime adaptasyon durumunda anlamlı farklar gözlemlense de cinsiyetin istatistiksel olarak anlamlı olmadığı saptanmıştır. Ayrıca dersin daha önce uzaktan eğitim ile verilmiş olması, öğrencilerin uzaktan eğitimde bu derste daha başarılı olması ile ilişkili bulunmuştur (Toti \& Alipour, 2021).

Çalışmalarda göze çarpan ortak bulgulardan bir diğeri de, yükseköğretimde salgın sonrası dönemde de uzaktan eğitimin talep göreceği hususudur. Didenko 
ve Filatova tarafından yapılan çalışmada karantinadan sonra YL programları için öğrenme biçiminin gözden geçirilmesinin ve geleneksel yüz yüze öğrenmeden karma ve hatta uzaktan öğrenmeye geçmenin faydalı olacağı saptanmıştır. Çalışmanın temel amacı, lisans ve lisans üstü programların birinci sınıfında eğitim gören öğrencilerin karşılaştığı zorlukları ve karantina altındaki eğitimde öğrencilerin memnuniyet düzeylerini belirlemektir. Bulgular YL düzeyindeki öğrencilerin yüksek memnuniyet düzeyine sahip olduğunu göstermektedir. Bunun nedeni olarak YL öğrencilerinin deneyimli ve yetkin olmaları, bu nedenle öğretim elemanlarından daha az taleplerinin olduğu, arka plan bilgilerinin internette gerekli verileri aramalarına izin verecek kadar yeterli olması, analitik düşünme ve muhakeme becerilerinin gelişmiş olması faktörleri belirtilmiştir (Didenko, Filatova, \& Anisimova, 2021). 2021 yılında yapılan bir başka çalışmada da gelecekte İtalya'da yükseköğretimde uzaktan eğitimin olağan ve yapılandırılmış bir uygulama haline geleceği öngörülmektedir. Bu çalışmada ayrıca COVID-19'a bağlı acil sağlık durumu gereği olarak uygulanan uzaktan eğitimin, geleneksel üniversiteler için "isteğe bağl1" olmaktan çıkarılarak halk sağlığını korumanın tek alternatifi haline dönüşümü dile getirilmiştir. Bu kapsamda İtalyan yükseköğretimi tarafından benimsenen stratejik uzaktan eğitim modeli, Belge Analizi ile detaylı olarak incelenmiştir. İlk kısımda, Üniversite ve Araştırma Sistemlerinin Değerlendirilmesi için İtalyan Ulusal Ajansı (ANVUR) ve araştırılan üniversiteler tarafından sağlanan resmî açıklamalar dikkate alınarak toplanmıştır. İkinci aşamada ise üniversitelerin eğitim sağlamak için kullandığı çevrimiçi platformların sayısına ve türüne ait veriler derlenmiştir. Elde edilen bulgulara göre Microsoft Teams, Google Meets ve Moodle, üniversiteler tarafından en çok tercih edilen çevrimiçi platform olarak belirlenmiştir. 38 üniversite tek bir program kullanırken, 22 üniversitenin iki platformu birden kullandıkları ortaya çıkmıştır. İtalyan üniversitelerinin uzaktan eğitime geçişi, mevcut teknolojik alt yapı ve çevrimiçi üniversiteler tarafından sağlanan eğitimin kalitesi hakkındaki olumsuz algı sebebiyle çok geç gerçekleşmiştir (Appolloni, Colasanti, Fantauzzi, Fiorani, \& Frondizi, 2021).

Salgın döneminde yükseköğretimde uzaktan eğitim sürecinin ele alındığı Türkiye adresli çalışmaların daha çok nitel yaklaşıma sahip olduğu tespit edilmiştir. Türkçe yayınlarda uzaktan eğitimin ortak bir dezavantajı olarak "sosyal iletişimin azalması" ve bir avantaj olarak "zaman kazanımı" sıklıkla vurgulanmaktadır. Kırıkkale Üniversitesi Sosyal Bilimler Enstitüsü'nde 7 YL öğrencisi ile yapılan nitel araştırmada, veriler yüz yüze görüşme ile toplanmış ve uzaktan eğitimi deneyimleyen öğrencilerin görüşleri incelenmiştir. Çalışmanın bulgularına göre katılımcılar için uzaktan eğitimin en avantajlı yönü zaman kazanımı olurken; en dezavantajlı yönleri ise iletişim-etkileşim eksikliği, internet altyapısı ve ifade aktarım güçlüğü olarak belirlenmiştir. Uzaktan eğitimin aynı anda hem avantaj hem de dezavantajı olacak şekilde çift yönlü etkisinde ise en yüksek skoru "derse erişim" almıştır. Katılımcıların çoğu yüz yüze eğitimi tercih etmekle birlikte; uzaktan eğitimin gelecekte daha da geliştirilerek, sadece zaruri durumlarda kullanılan bir alternatif olmaktan ziyade, kısmi dersler için yüz yüze eğitim yerine kullanılabilmesi açısından değerlendirilmelidir (Arar, Öneren, \& Yurdakul, 2021).

Erdem Aydın tarafından 2021 yılında yapılan çalışmada, lisans ve lisansüstü öğrencilerin acil uzaktan ögrenme deneyimleri, nitel veri analizi yöntemlerinden İçerik Analizi ile incelenmiştir. Elde edilen bulgulara göre öğrencilerin büyük bir çoğunluğu gelecekte uzaktan eğitimi tercih edeceklerini belirtmiş ve sebep olarak; esneklik, hayat akışına uygunluk, zaman yönetimi kolaylığı, kaynaklara erişim kolaylığı, tekrar izleme olanağı, kendi hızında öğrenme olanağı, masrafsız oluşu, kendine vakit ayırabilme, teknolojiyle öğrenmeyi deneyimleme faktörlerini dile getirmişlerdir. \%21'lik bir kısım ise yüz yüze eğitimi tercih edeceklerini söylemiș ve gerekçe olarak; derse motive olamama, sosyalleşememe, verimsizlik, disiplinsizlik, etkileşim azlığı ve yüz yüze eğitim sinerjisinin kurulamaması gösterilmiştir. Cevaplayıcılardan biri ise harmanlanmış eğitimin teorik dersler uzaktan, uygulamalı dersler ise yüz yüze olacak şekilde faydalı olacağını belirtmiştir (Erdem Aydın, 2021). Türkiye' de lisans ve lisansüstü öğrencilerinden online anket yöntemi ile toplanan verilerin incelendiği bir diğer çalışmada, öğrencilerin büyük bir çoğunluğunun uzaktan eğitimi tercih etmedikleri, uzaktan eğitimin yüz yüze eğitime göre daha avantajlı görüldüğü tek konunun "başka iş ve hobilere zaman ayırabilme" olduğu saptanmıştır. Tercih etmemeye gerekçe olarak yüz yüze eğitimin öğrenme çıktılarının daha verimli olduğu belirtilmiştir. YÖK tarafından uzaktan eğitim kararı verilecek derslerin, sözel ağırlıklı dersler olması talep edilmiştir. Uzaktan eğitim memnuniyetini negatif yönde etkileyen faktörlerin; fiziki, üniversite kaynaklı, 
psikolojik ve demografik faktörler olduğu saptanmıştır. Son olarak YL öğrencilerinin araştırma temellerinin gelişmiş olmasından kaynaklı olarak lisansüstü öğrenciler arasında uzaktan eğitimin destek gördüğü düşünülmektedir (Tüzün \& Yörük Toroman, 2020). Benzer şekilde Benzer ve Akkaya tarafından yapılan çalışmada lisans, YL ve doktora alanında eğitim gören 17 öğrencinin aldığı uzaktan eğitim İçerik Analizine tabii tutulmuştur. Katılımcıların uzaktan eğitimde karşılaştı̆̆ı en büyük sorunlar sırasıyla; "internete bağlanamama", "derslerde ses ve görüntü bozukluklarının olması", "uygun çalışma ortamının bulunmaması" "uygulamalı derslerin yapılamaması" ve "yüz yüze eğitimdeki gibi etkileşimin olamaması", olarak belirlenmiştir. Bunlara ek olarak dikkatlerinin çok çabuk dağıldığını, öğretim elemanları ile kolay iletişim kurulamadığını belirtmişlerdir. Uzaktan öğretimin avantajları arasında ise "derslerin tekrar izlenebilmesi" ve "okula yetişme derdinin olmaması" cevapları sıklıkla gözlenmiştir (Benzer \& Akkaya, 2021).

2020 yılında Çanakkale 18 Mart Üniversitesi Eğitim Bilimleri Enstitüsü'nde eğitim gören 14 gönüllü öğrenciden "öğrenci günlükleri” ve "yarı yapılandırılmış mülakat" yolu ile toplanan veriler, İçerik Analizi ve tanımlayıcı istatistikler ile analiz edilmiştir. Araştırmanın sonucunda, uzaktan eğitim ile verimi artan faktörler; "derslere fiziksel hazırlığın ortadan kalkması", "ders kayıtlarının ve materyallerinin ulaşılabilir olması", "öğretim elemanları ile iletişimin hızlanmasi", "öğretim elemanlarının destekleyici tavır ve yeterlikleri”, "üniversitenin uzaktan eğitim uygulamalarına hızlı adapte oluşu”, "öğrencilerin nitelikleri, zaman-para-emek acısından ekonomik oluşu”, “ödevlerin öğrencileri derse hazırlaması/dersten kopmayı önlemesi”, "öğretimsel görevlere verilen geribildirimler", "kaynaklara erişim kolaylığı sağlaması", "online eğitimlere katılım fırsatı" olarak ifade edilmiştir. Uzaktan eğitim sürecine olumsuz etki eden faktörler ise "derslerin bir günde yoğunlaşması”, " artan ödev yükü®”, “aile üyelerinden, dışarıdan gelen gürültüler", "öğretimsel görevlerin yeterli açılanmaması", "teknolojiye aşırı maruz kalma", "salgın kaynaklı sorunlar", "öğrenci nitelikleri”, "internet kaynaklı s1kıntılar", "sistemsel-teknolojik sorunlar", "kullanılan yöntemlerde tekdüzelik", "sinıf mevcutlarının fazlalığı”, “ders içeriklerinin öğrenciler tarafından sunulması" olarak belirtilmiştir (Genç, Engin, \& Yardım, 2020).

Öte yandan Arık tarafından 2021 yılında 3025 yükse- köğretim öğrencisi ile yapılan çalışmada, öğrencilerin uzaktan eğitim konusunda kararsız oldukları, ancak “öğrenci etkileşimi ve iş birliği” sonucunda öğrenci görüşlerinin uzaktan eğitim alanlar lehine önemli ölçüde farklılaştığı belirtilmiştir (Arık, 2021).

\section{METODOLOJIKK BİLGİLER}

Literatür özetinde görüldüğü gibi, Türkiye adresli çalışmalar daha çok nitel araştırma deseninde olup; genellenebilir bulgular elde etme amacı taşımamaktadır. Tarafımızca gerçekleştirilen bu çalışmada ise örneklemin demografik dağılımı ve yüksek hacmi, hedef kitleye ilişkin çıkarımlar yapılmasını mümkün kılacak şekilde tasarlanmıştır. Bu amaçla, 2020-2021 Akademik Yılı Bahar Dönemi'nde Marmara Üniversitesi bünyesindeki bir programa kayıt olan tüm YL öğrencilerine e-posta anketi uygulanmıştır.

Derlenen veri setinden öncelikle tanımlayıcı istatistikler elde edilmiş; belirlenen araştırma hipotezlerinin test edilmesi amacıyla ki-kare testi, $\mathrm{t}$ testi ve Tek Yönlü Varyans Analizi (ANOVA)'nden yararlanılmıştır. Öğrencilerin uzaktan eğitim deneyimlerinin alt boyutlarını tanımlamak amacıyla Faktör Analizi uygulanmıştır.

Araştırma kapsamında cinsiyet, medeni durum gibi iki şıklı nominal değişkenler için ki-kare bağımsızlık ve $t$ testleri uygulanmıştır. Örneklem hacminin yüksek olması sayesinde ki-kare testinin varsayımları yönünden sorun yaşanmamış; t testi sonuçları ise, grupların homojenlik bilgisi dikkate alınarak değerlendirilmiştir.

Başvurulan testlerden bir diğeri olan ANOVA, ikiden fazla grubun ortalamaları arasında anlamlı fark olup olmadığını belirlemek amacıyla kullanılmaktadır. Parametrik bir test olması nedeni ile metrik ölçek ile ölçülmüş verilere uygulanabilmektedir. ANOVA için verilerin normal dağılıma sahip olması ve eş varyans varsayımını sağlaması gerekir (Alpar, 2013). Gruplar arası fark saptandığı durumda, farklılığın hangi grup ya da gruplardan kaynaklandığını belirlemek için post hoc testleri (Tukey, Welch gibi) kullanılmaktadır (Mach \& Ponting, 2021). Çalışmada "yaş" değişkeni için ANOVA varsayımları sağlanmadığından Welch testi uygulanmıştır.

Uzaktan eğitim hakkında görüşleri kapsayan likert ölçekli 29 ifade, Faktör Analizi'ne tabi tutularak YL öğrencilerinin perspektifinden uzaktan eğitim algısının 
alt boyutları belirlenmeye çalışılmıştır. Faktör Analizi, aralarında önemli ölçüde korelasyon bulunan çok sayıda değişkenden elde edilen bilgiyi özetleyecek daha az sayıda yeni/gizli değişken (faktör) elde etmeyi amaçlar. Bu analizde bağımlı yapıdaki çok sayıda değişkenin bağımsızlaştırılması, kavramsal anlamlılı$\breve{g} ı n$ sağlanması ve boyut indirgeme hedeflenir (Hair, Black, Babin, \& Anderson, 2010).

Zpxn: Standartlaştırılmış Değerler Matrisi

Fmxn: Faktör Matrisi

Apxm: Faktör Yükleri Matrisi

Upxn: Artık Faktör Matrisi

Bpxp: Artık Faktör Katsayıları Matrisi

olmak üzere Faktör Analizi modeli aşağıda verilmiştir.

\section{$\mathrm{Z}=\mathrm{A} F+\mathrm{B} U$}

\section{BULGULAR}

YL öğrencilerine e-posta yoluyla gönderilen ankete katılan ve soruları eksiksiz yanıtlayan öğrenci say1s1 501'dir. Örneklemin demografik yapısı Şekil 1'de özetlenmiştir.

Ankete katılan öğrenciler 23-56 yaş aralığında olup; medyan yaş 27 'dir. \%55'i 23-27 yaş grubunda, \%22'si 28-32 yaş grubunda, \%23'ü 33 yaş ve üzerindedir. \%59'u erkek, \%41'i kadındır. \%54'ü tam zamanlı, \%12'si yarı zamanlı bir işte çalışmaktadır. \%34'ü bir işte çalışmadığını belirtmiştir. Evli öğrencilerin oranı $\% 24$ 'tür. Evli öğrencilerin \%42'si çocuk sahibi olmayıp; çocuk sahibi öğrencilerin ortalama çocuk sayısı 1'dir. Öğrencilerin \%74'ü tezli, \%26's1 tezsiz bir YL programına kayıtlıdır.

Öğrencilerin eğitim aldıkları YL programlarının alan bazında dağılımı Şekil 2'de verilmiştir. Öğrencilerin \%71'i sosyal bilimler, \%19'u fen bilimleri, \%8'i sağlık bilimleri alanlarındaki programlara kayıtlıdır. Örneklemde güzel sanatlar alanından 11 öğrenci bulunduğu için, istatistiksel olarak ilgili alanı temsil etmede yeterli olmayacakları düşüncesiyle, ilerleyen kısımlarda bazı analizlere dahil edilmemişlerdir.

Şekil 2. YL Programı Alanına Göre Dağılımı

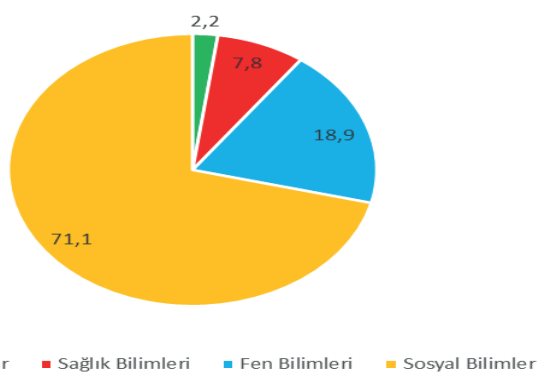

Araştırmaya katılan YL öğrencilerinin COVID-19 salgınının etkileri hakkındaki görüşleri genel olarak incelendiğinde; Şekil 3'te görüldüğü gibi, salgının kendi eğitim sürecine olumlu etki ettiğini düşünenler ile olumsuz etki ettiğini düşünenlerin denk iki grup oluşturduğu görülmüştür. \%13’lük kararsız bir kesim

Şekil 1. Örneklemin Demografik Dağılımı
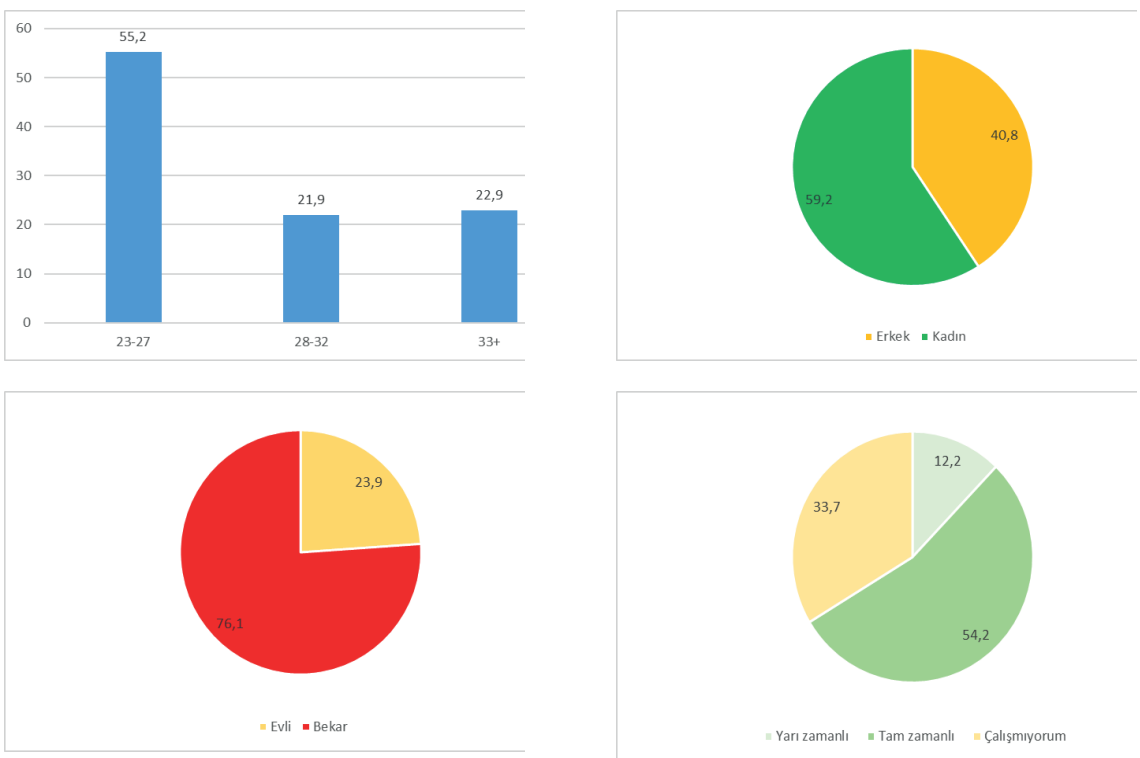
de söz konusudur.

Şekil 3. Salgın Sürecinin Eğitim Hayatına Etkisi

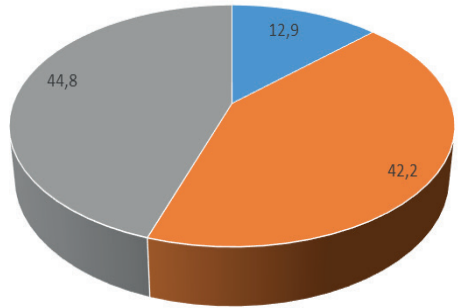

- Eg̈̈tim sürecime etkisi olmadı - Eg̈itim sürecime olumsuz etkisi oldu Eğitim sürecime olumlu etkisi oldı

Salgın sürecinin eğitim hayatına etkisi hakkındaki görüşler ile YL program türü arasında istatistiksel olarak anlamlı bir ilişki tespit edilmiştir $(\chi 2=28,771$; $\mathrm{p}=0,0001)$. Tezli YL öğrencilerinin \%39'u salgının eğitim hayatlarına olumlu etkisi olduğunu düşünürken; tezsiz YL öğrencilerinde bu oran \%62'dir. Salgının eğitimlerine olumsuz etkisi olduğunu düşünenler tezli YL öğrencilerinin \%49’u iken, tezsiz YL öğrencilerinin \%23'üdür.

Öğrencilerin çalışma durumları ile salgın sürecinin eğitim hayatına etkisi hakkındaki görüşler arasında da anlamlı bir ilişki tespit edilmiştir $(\chi 2=33,778$; $\mathrm{p}=0,001)$. Bir işte çalışmayanların çoğu (\%56) salgının eğitim süreçlerine olumsuz etkisi olduğunu düşünürken; tam zamanlı çalışanların çoğu (\%55) ve yarı zamanlı çalışanların \%44'ü salgının etkisinin olumlu olduğunu düşünmektedir.

Salgın sürecinin eğitim hayatına etkisi hakkındaki görüşler, cinsiyet ve programın ilgili olduğu alan bazında anlamlı bir fark ortaya koymamaktadır.

Öğrencilerin YL yapma kararlarında etkili olan faktörler önem derecelerine göre siralandığında; Şekil 4 'te verilen bulgular elde edilmiştir. En etkili faktörün "öğrencilerin kariyer hedefleri" olduğu, sonraki etkili faktörlerin ise sırasıyla "uzmanlaşma isteği”, "öğren- ciliklerini sürdürmek", "boş zamanlarını değerlendirmek" ve "arkadaş tavsiyesi" olduğu görülmüştür.

Öğrencilere ayrıca “YL programının uzaktan eğitimle gerçekleştirilmesi, YL yapma kararınızda etkili oldu mu" sorusu da yöneltilmiş; Şekil 5'te görüldüğü gibi öğrencilerin yaklaşık 1/5'i uzaktan eğitim yapıldığ için YL yapmaya karar verdiğini belirtmiştir.

Şekil 5. Uzaktan Eğitimin YL yapma kararına etkisi

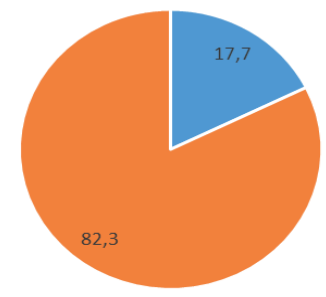

- Evet, uzaktan eğitim yapılacağı için yüksek lisans yapmayı düşündüm

- Hayır, eğitim hangi biçimde yapılırsa yapılsın yüksek lisans yapmayıı planlıyordum

İlgili iki soruya verilen cevaplar birlikte değerlendirildiğinde, eğitimin uzaktan uygulanacak olmasının YL yapma kararında teşvik edici bir faktör olduğu anlaşılmaktadır.

YL program türü ile uzaktan eğitim uygulanacak olmasının YL kararına etkisi arasında anlamlı bir ilişki bulunmuştur $(\chi 2=23,509 ; p=0,001)$. Tezli YL öğrencilerinin \%13'ü uzaktan eğitim yapılacağı için YL yapma kararı aldığını belirtirken; tezsiz YL öğrencilerinde bu oran \%32'dir. Uzaktan eğitim uygulanmasının özellikle tezsiz YL öğrencilerinde motivasyon yarattığ söylenebilir.

YL programının alanı ile uzaktan eğitim uygulanacak olmasının YL kararına etkisi arasında anlamlı bir ilişki bulunmuştur ( $\chi 2=15,527$; $p=0,001)$. Araştırmanın başında öne sürülen hipotezin aksine, dört alan arasında uzaktan eğitim uygulanacağı için YL yapma kararı alan en büyük kitle (\%31) fen bilimleri alanında tespit edilmiştir. İlgili kitle, sosyal bilimler alanındaki

Şekil 4. YL Yapma Kararında Etkili Olan Faktörler

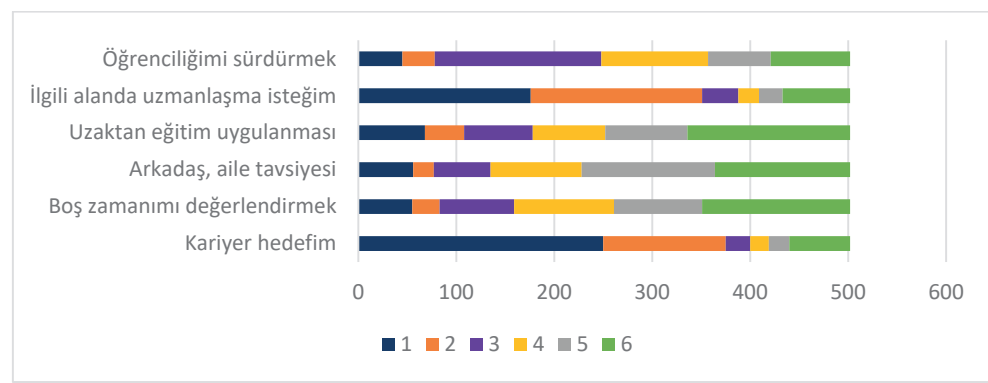


öğrencilerin \%16's1, sağlık bilimlerindeki öğrencilerin \%5'ini oluşturmaktadır.

Şekil 6'da verildiği üzere, genel olarak öğrencilerin çoğunun (\%57) salgın öncesinde herhangi bir uzaktan eğitim deneyimi olmadı̆̆ı, bununla birlikte tezsiz programlarda uzaktan eğitim deneyimi olan öğrencilerin oranının nisbi olarak daha yüksek olduğu anlaşılmıştır. Tezsiz YL programlarındaki öğrencilerin yarısı, tezli programlardakilerin \%41'i daha önce uzaktan eğitim almıştır.

Şekil 6. Salgın Öncesinde Uzaktan Eğitim Deneyimi

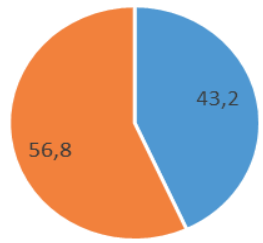

- Salgın öncesinde uzaktan eğitim deneyimi olanlar

- Salgın öncesinde uzaktan eğitim deneyimi olmayanlar
Daha önceden uzaktan eğitim deneyimi olmayan 285 öğrencinin uzaktan eğitime geçiş sürecinde zorluk yaşayıp yaşamadığı incelendiğinde, Şekil 7'de görüldüğü gibi, 1/5'inin önemli zorluklar yaşadığı tespit edilmiştir.

YL programında hangi uzaktan eğitim platformlar1nın kullanıldı ̆̆ı incelendiğinde, Şekil 8'de sunulduğu üzere, Zoom programının açık farkla öne çıktığ1 (\%88), ardından en sık kullanılan platformun Marmara Üniversitesi Uzaktan Eğitim Merkezi'nin önerdiği Perculus (\%52) olduğu anlaşılmıştır. Sıkça tercih edilen diğer platformlar, Skpye, Google Classroom ve MS Teams'tir.

Öğrencilere uzaktan eğitim için kendi platform tercihleri sorulduğunda, Şekil 9'da görüldüğü gibi, \%83'ü Zoom programını belirtmekle birlikte; Perculus tercih oranı önemli ölçüde düşüş göstermiş, sırasıyla MS Teams, Google Classroom ve Skpye kullanımının önerildiği kaydedilmiştir.

YL programında uzaktan eğitim sistemine hangi cihazlardan bağlanıldığı sorulduğunda, öğrencilerin

Şekil 7. Geçiş Sürecinde Zorluk Yaşama

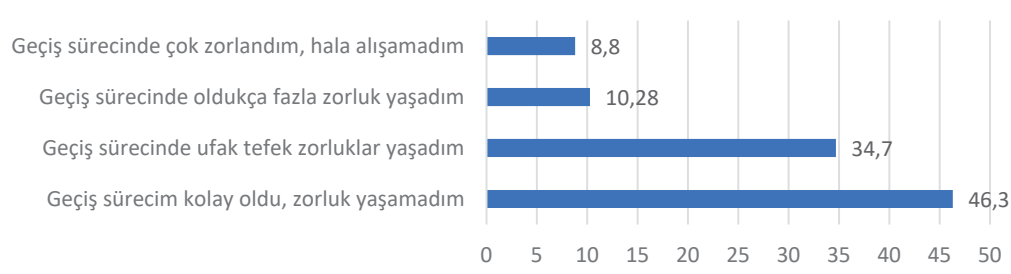

Şekil 8. Eğitimde Kullanılan Platformlar

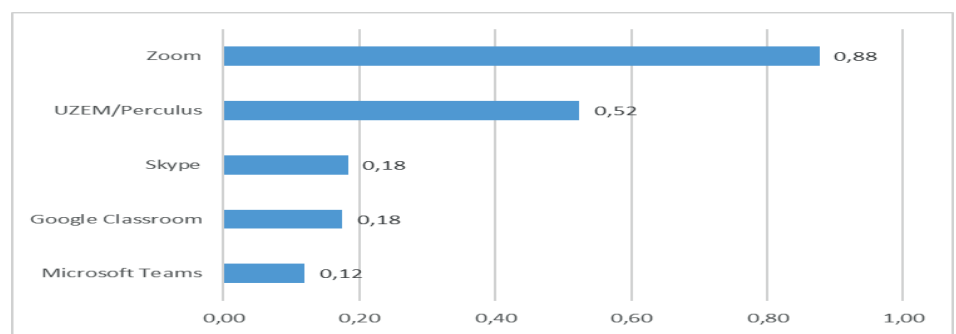

Şekil 9. Öğrencilerin Platform Tercihleri

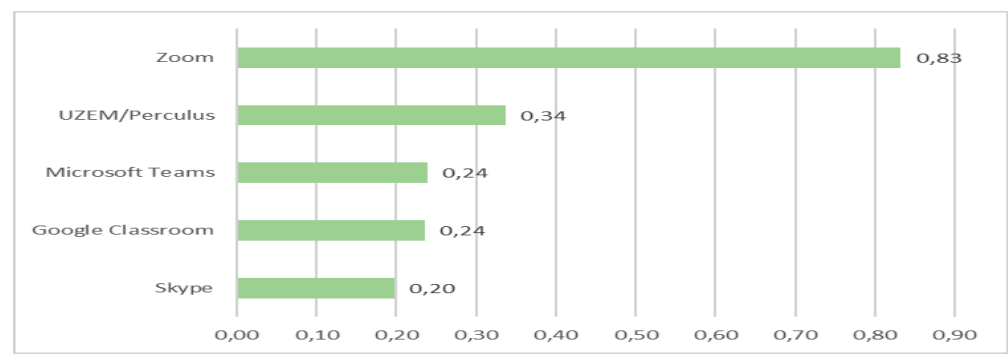


tamamına yakınının (\%96) bilgisayarı tercih ettiği, yarıdan fazlasının (\%56) cep telefonu üzerinden bağlantı kurduğu anlaşılmıştır. İlgili grafik Şekil 10'da verilmiştir.

Tezli ve tezsiz YL öğrencilerinin ders bağlantısı için bilgisayar kullanım oranı aynı olmakla birlikte; tezsiz YL öğrencilerinden cep telefonundan ve tabletten derse bağlanma sıklığı daha yüksektir. Cep telefonundan derse bağlanma oranı tezsiz YL öğrencilerinde \%68, tezli YL öğrencilerinde $\% 52$ 'dir. Tabletten derse bağlanma oranı da sirasiyla $\% 18$ ve $\% 8^{\prime}$ dir.

Uzaktan eğitim sürecinde (hem ders hem de sinav esnasında önemli bir sorun olarak öğrenciler tarafından sıkça dile getirilen) kişisel internet bağlantılarının ka- litesi sorulduğunda; söz konusu sıkıntının yaygın olduğu anlaşılmıştır. Şekil 11'de verildiği üzere, öğrencilerin 1/4'ü önemli ölçüde bağlantı sorunu yaşadığını, hatta \%4'ü sorunun sürekli olduğunu belirtmiştir.

Öğrencilere salgın sürecindeki uzaktan eğitim deneyimlerine dair çok sayıda soru yöneltilerek; uzaktan eğitim ile yüz yüze eğitimi karşılaştırmaları istenmiştir. Öğrenciler tarafından dile getirilen görüşler analiz edilerek; en yüksek katılım bildirilen görüşler (5 üzerinden ortalama puanları ile birlikte) Şekil 12' de verilmiştir.

En fazla görüş birliği tespit edilen iki konu, "uzaktan eğitimin öğrenciler arasındaki iletişimi sekteye uğratması yönünden dezavantajı" ile "ders kayıtlarının

Şekil 10. Öğrencilerin Tercih Ettiği Cihazlar

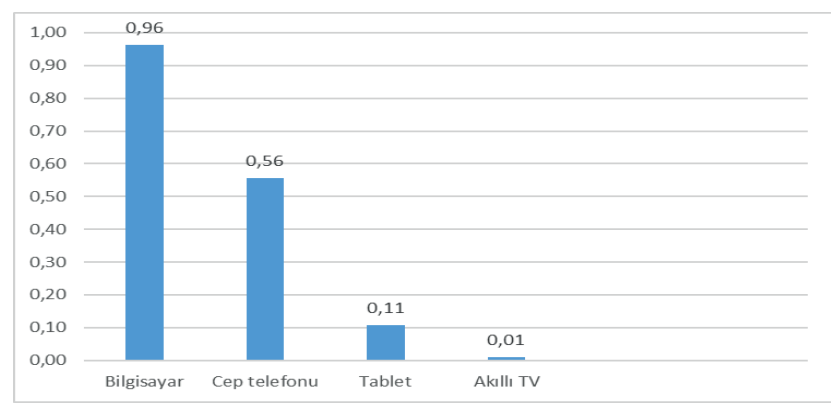

Şekil 11. Öğrencilerin Bağlantı Kalitesi

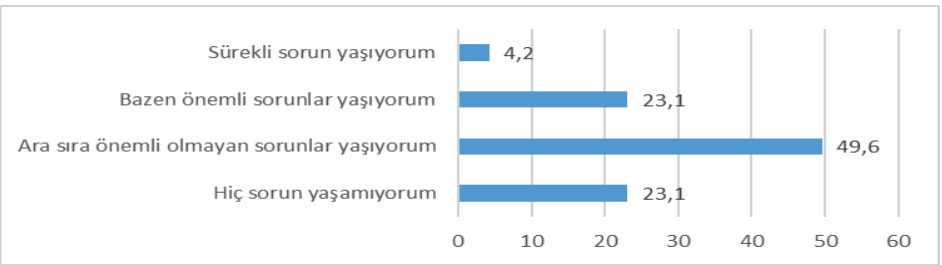

Şekil 12. Uzaktan Eğitimle Öğrenme Deneyimine Dair Görüşler

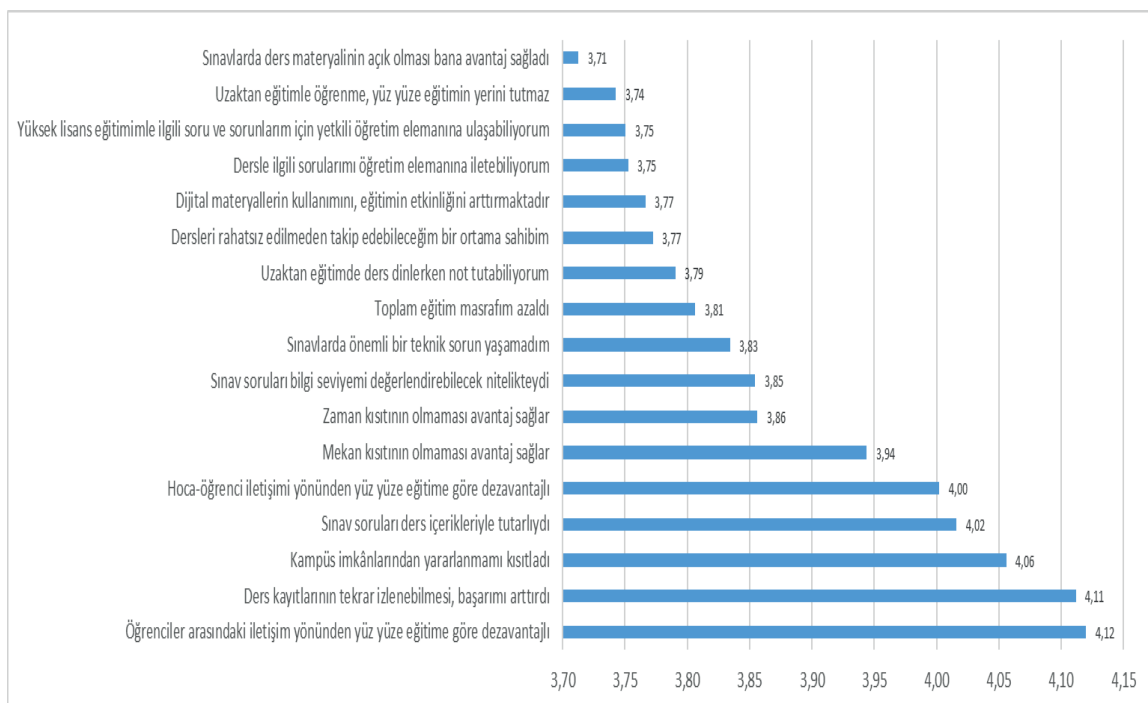


tekrar tekrar izlenebilmesi konusundaki avantajıdır". Daha sonra önem sırasıyla, "kampüs olanaklarından yararlanma" ve "öğretim elemanları ile öğrenciler arasındaki iletişim” yönlerinden uzaktan eğitimin yüz yüze eğitime göre dezavantajlı olması ile "sınav sorularının ders içerikleri ile tutarlılığ1" konularında yüksek oranda fikir birliği tespit edilmiştir. "Mekan ve zamandan bağımsız eğitim yapılması", "sınavların bilgi seviyelerine uygun olması" ve "sinav uygulamasının sorunsuz yapılması”, "toplam eğitim masrafının azalması" avantaj olarak vurgulanan öncelikli konulardır.

Uzaktan eğitimle ilgili olumlu puanı en düşük olan hususlar incelendiğinde, "uzaktan eğitimin yüz yüze eğitim kadar keyifli ve verimli olmadığı" görüşünün hakim olduğu söylenebilir. Bununla birlikte, öğrencilerin "uzaktan eğitim sürecinde zaman yönetimini" bir sorun olarak görmedikleri söylenebilir. İlgili grafik Şekil 13'te verilmiştir.

Uzaktan eğitim uygulamasının etkinliğinin ölçülmesinde önemli bir unsur olarak, öğrencilere ders programları içinde uygulamalı derslerinin ağırlığı sorulmuştur. Şekil 14'e göre öğrencilerin \%69'unun hiç uygulamalı dersi bulunmazken; \%11'inin en az teorik dersler kadar uygulamalı dersi bulunmakta, \%2'sinin tüm dersleri uygulamalı olarak gerçekleştirilmektedir.

YL derslerinde uygulanan öğretim metotları incelendiğinde, Şekil 15'te görüldüğü gibi yaygın olarak slayt/sunum destekli olarak canlı ders yapıldı̆̆ $1 \% 93$ ) anlaşılmaktadır. Öğrencilerin \%72'si ders notu paylaşıldığını, \%58'i akademik yayın okutulduğunu, \%43'ü slayt/sunum olmaksızın canlı ders yapıldığını belirtmiştir. Derslerde beyaz tahta kullanımının düşük düzeyde olduğu (\%17), video ile asenkron ders oranının en az tercih edilen (\%13) yöntem olduğu anlaşılmaktadir.

Uzaktan eğitimde kullanılan ders materyalinin içerik kalitesi hakkında görüşleri sorulduğunda, Şekil 16'da verildiği üzere, öğrencilerin \%75'inin içerikleri beğendikleri tespit edilmiştir.

Şekil 13. Uzaktan Eğitimle Öğrenme

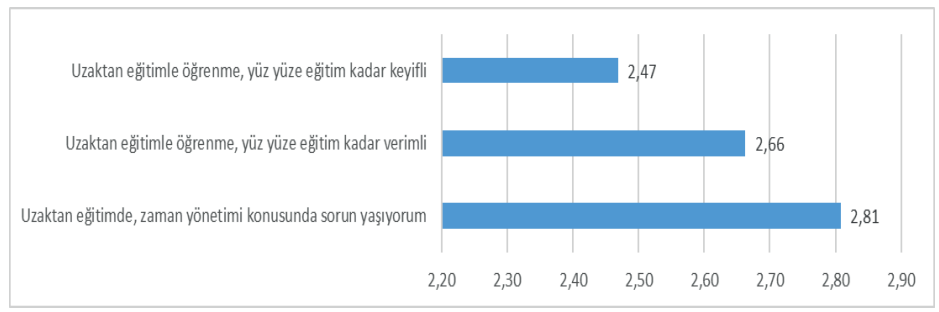

Şekil 14. Eğitimde Uygulamalı Derslerin Ağırlığı

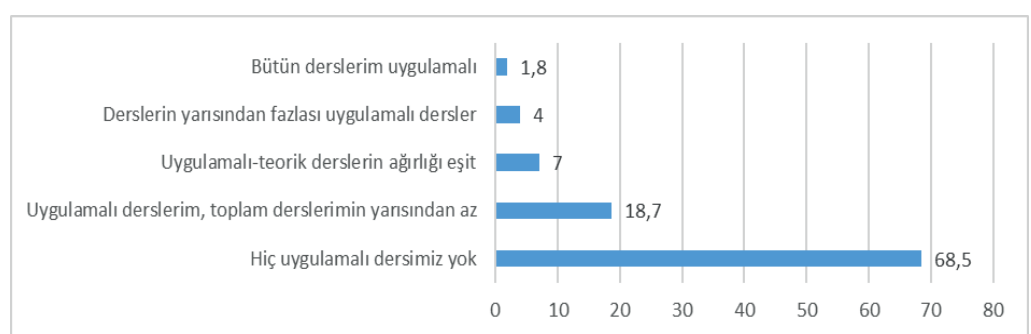

Şekil 15. Ders Uygulanma Biçimleri

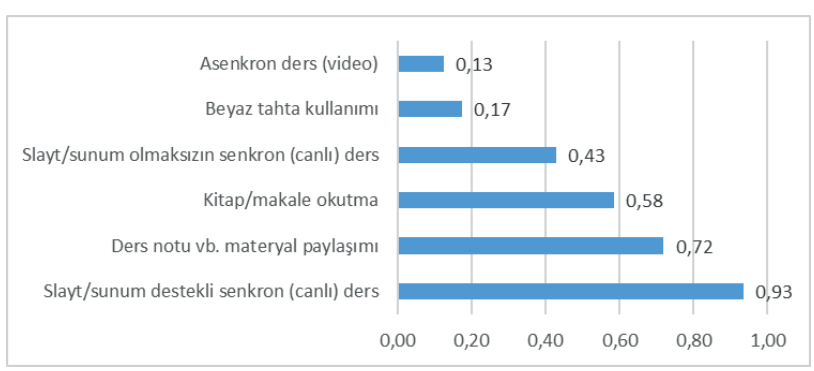


Şekil 16. Ders Materyalinin İçerik Kalitesi

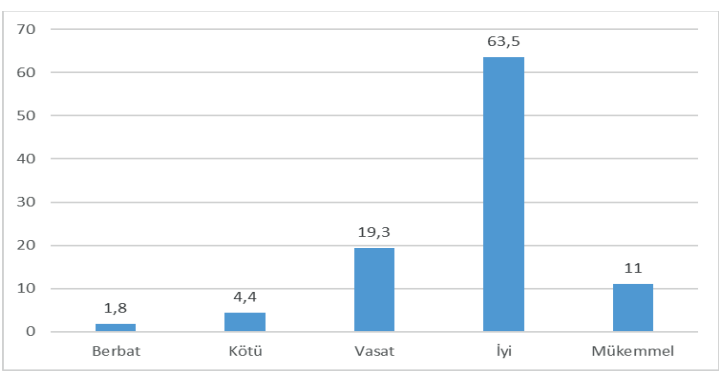

Öğrencilere “öğrenme çıktıları, öğrenim sürecinin tamamlanmasının ardından öğrencinin ne bileceği$\mathrm{ni}$, ne anlayabileceğini veya ne yapabileceğini ifade eden yeterliliklerdir. Uzaktan eğitim ‘öğrenme çıtıları bakımından yüz yüze eğitimle karşılaştırıldığında, üstünlük derecesini nasıl değerlendirirsiniz" sorusu yöneltilmiştir. Öğrencilerin çoğu (\%57) yüz yüze eğitimi daha üstün bulurken (hatta \%24'lük kesim “kesinlikle" üstün olduğunu belirtmiştir), \%28'i uzaktan eğitimi üstün olarak değerlendirmektedir.

Öğrenme çıktıları yönünden değerlendirmeler ile öğrencilerin yaşları arasında anlamlı bir ilişki bulunmuştur ( $\chi 2=16,466,539 ; p=0,002)$. Yaş arttıkça uzaktan eğitimin üstün olduğuna dair eğilim artmakta; yüz yüze eğitimin üstün olduğunu düşünenlerin oranı azalmaktadır.

Öğrenme çıktıları yönünden değerlendirmeler ile medeni durum arasında anlamlı ilişki bulunmuştur $(\chi 2=14,465 ; p=0,01)$. Evli öğrenciler uzaktan eğitimi, bekar öğrenciler yüz yüze eğitimi üstün bulma eğilimindedir. Evli öğrenciler arasında uzaktan eğitimi daha üstün bulanların oranı \%42 iken, bekarlarda bu oran \%24'tür. Yüz yüze eğitimi üstün bulanlar bekar öğrencilerin \%60'ını, evli öğrencilerin \%45'ini oluşturmaktadır.
Öğrenme çıktıları yönünden değerlendirmeler ile bir işte çalışma durumu arasında anlamlı ilişki bulunmuştur ( $\chi 2=19,296 ; p=0,01)$. Uzaktan eğitimi üstün bulanların oranı tam zamanlı çalışanlarda \%35 iken, çalışmayan ve yarı zamanlı çalışanlarda daha düşüktür (sırasıyla \%18 ve \%23). Çalışmayan ve yarı zamanlı çalışanlarda yüz yüze eğitimi üstün bulanların oranları (sırasıyla \%65-67), tam zamanlı çalışanlarda $\% 49^{\prime}$ dur.

Öğrenme çıktıları yönünden değerlendirmeler ile ders programında uygulama derslerinin ağırlık düzeyi arasında anlamlı bir ilişki bulunmuştur $(\chi 2=11,539$; $\mathrm{p}=0,021)$. Uygulama derslerinin ağırlığ sun, öğrencilerin çoğu yüz yüze eğitimi daha verimli bulmaktadır. Bununla birlikte; uygulama derslerinin ağırlığ1 teorik derslerden yüksek olan programlarda yüz yüze eğitimi daha verimli bulanların oranı $\% 76$ iken, uygulama derslerinin ağırlığı teorik derslerden az olan programlarda bu oran $\% 55^{\prime}$ tir.

Öğrenme çıktıları yönünden görüşlerle program türü (tezli/tezsiz) arasında anlamlı bir ilişkiye rastlanmamıştır.

Öğrencilere uzaktan eğitim ile ilgili olarak en fazla memnuniyetsizlik duydukları hususları sıralamaları istendiğinde, en çok vurgulanan husus "öğrenciler arası iletişimin az olması" ve "öğretim üyeleri ile iletişimin az olması", özetle iletişim kurma zorluklarıdır. Daha sonra sırasıyla, "uygulama yapma olanağının sınırlı olması", "öğrenme çıktıları yönünden eğitim kalitesinin düşmesi", "uzaktan eğitim uygulanan platformun yetersiz olması" ve "ders işlenme yöntemlerinin uygun olmaması" hususları belirtilmiştir. İlgili bulgular Şekil 17'de verilmiştir.

Şekil 17. Uzaktan Eğitimde Memnuniyetsizlik Duyulan Hususlar

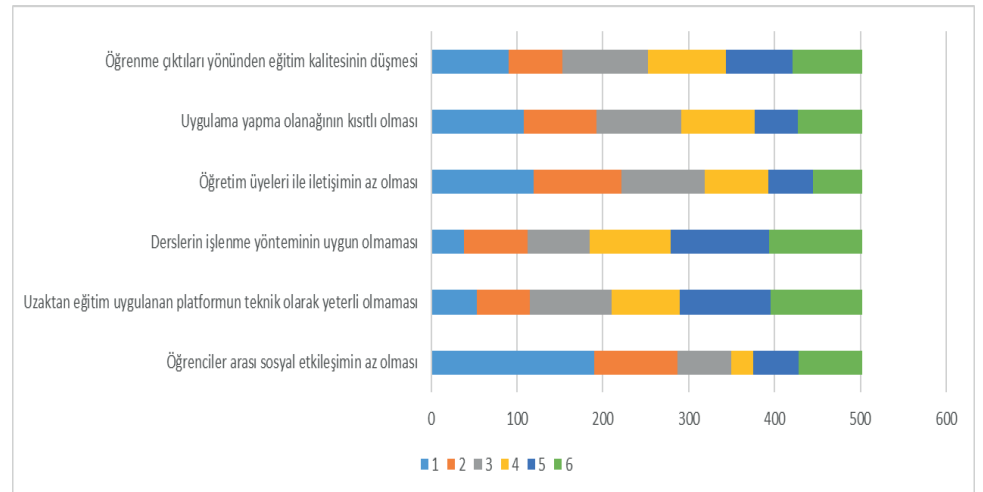


Şekil 18. Sınavların Uygulanma Şekli

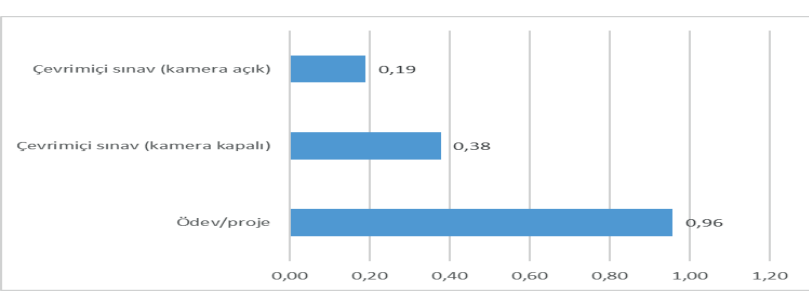

Sınavların uygulanma şekli incelendiğinde, Şekil 18 'de verildiği gibi, öğrencilerin tamamına yakını (\%96) ödev ya da proje biçiminde sınav uygulandığı$\mathrm{n}$, ayrıca kamera açık çevrim içi sınav (\%38) ve kamera açık çevrim içi sınav (\%19) uygulandığını dile getirmişlerdir.

Ödev/proje biçiminde sınav uygulanma oranı, fen bilimleri ve sosyal bilimlerde yakın iken (\%95 ve \%97), sağlık bilimlerinde nispeten daha düşüktür (\%87). Çevrimiçi sınav (kamera kapalı) oranı fen bilimlerinde en yüksek (\%67), sağlık ve sosyal bilimlerde birbirine yakın seviyededir (\%31 ve \%33).

Program türüne göre ödev/proje biçiminde ve çevrimiçi (kamera kapalı) sınav uygulanma oranları arasında önemli bir fark yoktur. Ancak, çevrimiçi (kamera açık) sınavlar yönünden önemli bir fark söz konusudur. Çevrimiçi (kamera açık) uygulanma oranı tezli programlarda \%29 iken, tezsiz programlarda \%64 olarak tespit edilmiştir.

Öğrencilere uzaktan eğitim sayesinde yüz yüze eği-

Şekil 19. Boş Zaman Değerlendirme Faaliyetleri

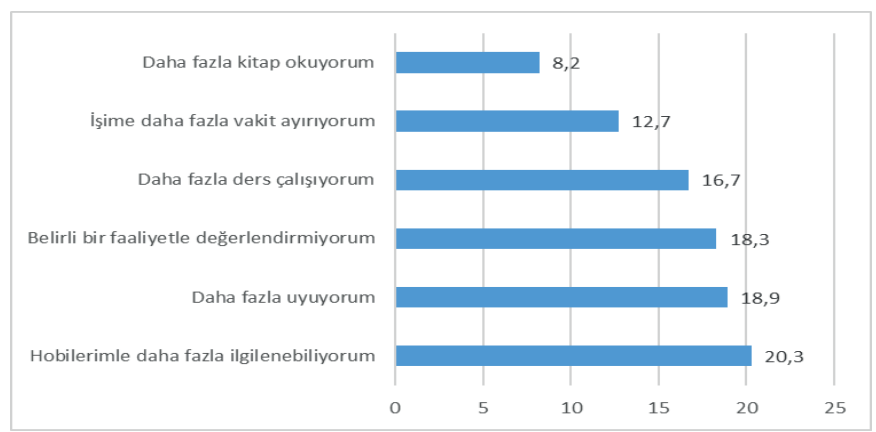

Tablo 1. Boş Zaman Değerlendirme - Program Türü

\section{Aktivite}

Daha fazla uyuyorum

Daha fazla ders çalışıyorum

Daha fazla kitap okuyorum

Hobilerimle daha fazla ilgilenebiliyorum

Belirli bir faaliyetle değerlendirmiyorum
Tezli YL Tezsiz YL

$21,7 \% \quad 10,0 \%$

$15,5 \% \quad 20,2 \%$

$7,5 \% \quad 10,1 \%$

$21,2 \% \quad 17,8 \%$

$16,1 \% \quad 21,7 \%$ 
Uzaktan eğitimin sağladığı ekstra zamanı değerlendirme şekli ile medeni durum arasında da anlamlı ilişki bulunmuştur ( $\chi 2=26,441 ; \mathrm{p}=0,001)$. Tablo 2 ' de görüldüğü gibi, bekar öğrenciler arasında ekstra zamanını daha fazla uyuyarak, hobileriyle ilgilenerek geçirenler çoğunlukta iken; evli öğrencilerde daha fazla ders çalışarak değerlendirenler çoğunluktadır.

Uzaktan eğitimin sağladığı ekstra zamanı değerlendirme şekli ile çalışma durumu arasında da anlamlı ilişki bulunmuştur ( $\chi 2=54,053 ; p=0,001)$. Tablo 3 'te görüldüğü gibi, çalışmayan öğrenciler arasında ekstra zamanını daha fazla uyuyarak, hobileriyle ilgilenerek geçirenler çoğunlukta iken; tam zamanlı çalışan öğrencilerde daha fazla ders çalışarak, belirli bir faaliyetle ilgilenmeyerek, hobileriyle ilgilenerek değerlendirenler çoğunluktadır. Yarı zamanlı çalışanların çoğu hobileriyle ilgilenmekte ya da amaçlı bir faaliyetle ilgilenmemektedirler.

Zaman zaman uzaktan eğitimde derslere katılmad1ğını ifade eden YL öğrencilerinin oranı \%57'dir. Ö $\breve{g}$ rencilere derslere istikrarlı olarak katılmama sebepleri sorulduğunda, Şekil 20'ye göre, işlerinin/çalışma koşullarının elvermemesi sıkıntısı (183 kişi) öne çıkmaktadır. Diğer faktörler incelendiğinde, ortamın ya da psikolojilerinin uygun olmaması ve donanım/bağlantı problemleri sıklıkla dile getirilmiştir. Sırasıyla derse motive olamama, ev ortamlarınin uygun olmamasi/ çocuklarıyla ilgilenme gereği, dersleri keyifli bulmama, takip etme ihtiyacı hissetmeme, internet erişiminin sinırlı olması, bilgisayar vb. imkanın kısıtlı olması derslere katılımı kısıtlayan etkenler olarak belirtilmiştir.

Tablo 2. Boş Zaman Değerlendirme - Medeni Durum

\begin{tabular}{|l|r|r|}
\hline Aktivite & Bekar & \multicolumn{1}{|c|}{$\boldsymbol{E v l i}$} \\
\hline Daha fazla uyuyorum & $21,70 \%$ & $10,00 \%$ \\
\hline Daha fazla ders çalışıorum & $15,20 \%$ & $21,70 \%$ \\
\hline Daha fazla kitap okuyorum & $8,10 \%$ & $8,30 \%$ \\
\hline Hobilerimle daha fazla ilgilenebiliyorum & $22,50 \%$ & $13,30 \%$ \\
\hline Belirli bir faaliyetle değerlendirmiyorum & $18,10 \%$ & $15,80 \%$ \\
\hline
\end{tabular}

Tablo 3. Boş Zaman Değerlendirme - Çalışma Durumu

\begin{tabular}{|l|l|l|l|}
\hline Aktivite & Çalışmayan & Tam Zamanlı Çalışan & Yarı Zamanlı Çalışan \\
\hline Daha fazla uyuyorum & $30,8 \%$ & $12,5 \%$ & $14,8 \%$ \\
\hline Daha fazla ders çalışıorum & $14,8 \%$ & $18,0 \%$ & $16,4 \%$ \\
\hline Daha fazla kitap okuyorum & $8,9 \%$ & $8,5 \%$ & $4,9 \%$ \\
\hline Hobilerimle daha fazla ilgilenebiliyorum & $24,3 \%$ & $15,8 \%$ & $29,5 \%$ \\
\hline Belirli bir faaliyetle değerlendirmiyorum & $13,6 \%$ & $18,4 \%$ & $24,6 \%$ \\
\hline
\end{tabular}

Sekil 20. Derse Katılmama Nedeni

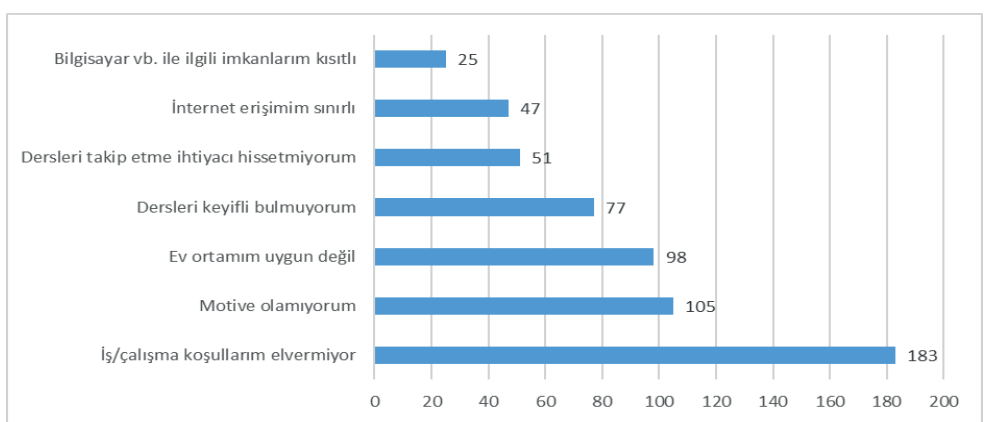


Şekil 21'de verildiği üzere, öğrencilerin \%68'i aldıkları YL eğitiminin genel olarak beklentilerini karşıladığ1$\mathrm{n}$ ifade etmiştir. Memnuniyet düzeyi ile öğrencilerin yaşları arasında anlamlı bir ilişki bulunmuştur $(\chi 2=$ 10,892; $\mathrm{p}=0,028)$. Yaş arttıkça memnuniyet düzeyi de artmaktadır.

Öğrencilerin aldıkları YL eğitiminden memnuniyetleri ile çalışma durumları arasında anlamlı bir ilişki bulunmuştur ( $\chi 2=13,928$; $p=0,008$ ). Memnuniyet oranı tam zamanlı çalışanlarda en yüksek düzeydedir (\%75). Buna mukabil, memnuniyetsizlik oranı da çalışmayanlarda en yüksektir (\%15).

Öğrencilerden YL eğitimleri ile ilgili belirtilen nitelikleri 10 üzerinden değerlendirmeleri istenmiş; elde edilen ortalama beğeni puanları Şekil 22'de verilmiştir. Genel olarak tüm nitelikler yönünden öğrencilerin verdiği karnenin başarılı olduğu söylenebilir. En yük- sek beğeni düzeyi (7,8 puan) “öğretim elemanlarının yetkinliği" konusunda tespit edilmiştir. Daha sonra sırasıyla "eğitim programının içeriği", "öğretim elemanlarının uzaktan eğitim performansı”, "başarı ölçme-değerlendirme sistemi" ve "sınıftaki diğer öğrencilerin akademik seviyesi" yönünden ortalama 7 puan civarındadır. "Üniversitenin uzaktan eğitim sistemi" ve "sorun çözme becerisi" 5,5 puan alırken, en düşük beğeni "öğrenciler arasındaki sosyal iletişim” yönünden kaydedilmiştir.

Salgın süreci sona erdiğinde, tercih edecekleri eğitim biçimi sorulduğunda, öğrenciler arasında gözlemlenen en büyük grubun hibrit (yüz yüze + uzaktan) eğitimi tercih edenler olduğu (\%48) anlaşılmıştır. Yüz yüze eğitim yapılmasını tercih edenlerin oranı \%34, uzaktan eğitimi tercih edenlerin oranı $\% 18^{\prime}$ dir. İlgili grafik Şekil 23'te yer almaktadır.

Şekil 21. Uzaktan Eğitimin Beklenti Karşılama Düzeyi

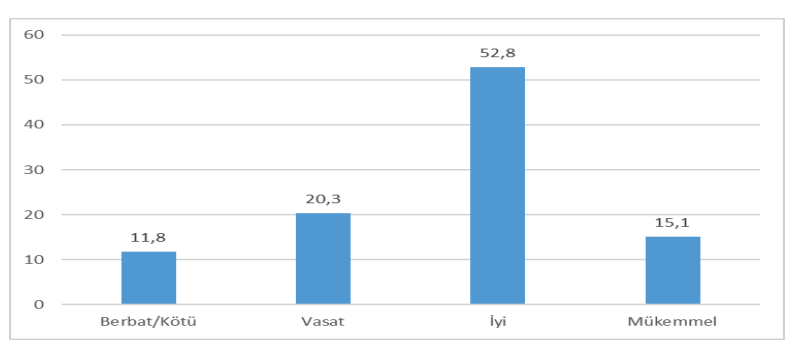

Şekil 22. YL Eğitiminde En Beğenilen Hususlar

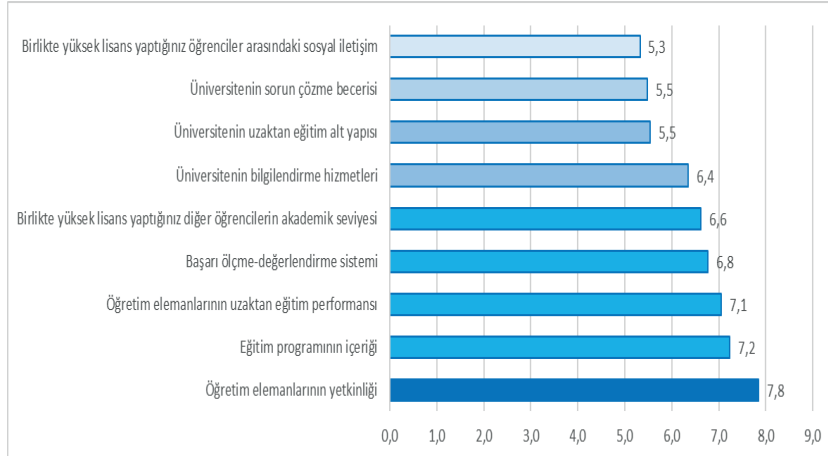

Şekil 23. Salgın Sonrası Eğitim Biçimi Tercihi

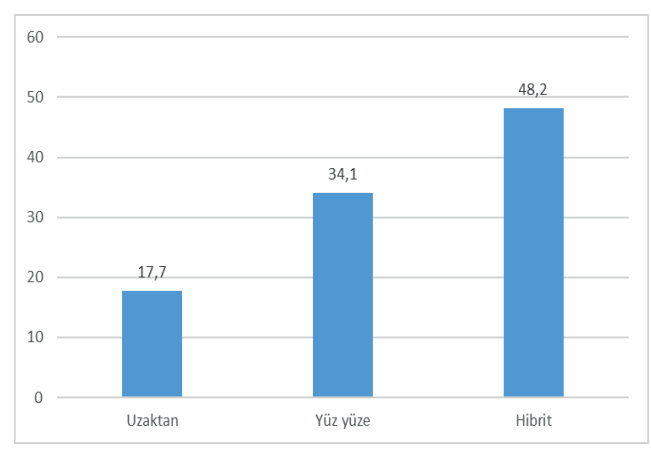


Salgın sonrası eğitim biçimi tercihi ile medeni durum arasında anlamlı bir ilişki bulunmuştur $(\chi 2=14,788$; $p=0,001$ ). Hibrit eğitim her iki grup tarafından da en çok tercih edilen opsiyon olmakla birlikte; bekar öğrencilerde yüz yüze eğitime eğilim, evli öğrencilerde uzaktan eğitime eğilim daha yüksektir. Yüz yüze eğitimi tercih edenler bekar öğrencilerin \%38'i, evli öğrencilerin \%23'ü; uzaktan eğitimi tercih edenler bekar öğrencilerin \%15'i, evli öğrencilerin \%28'idir.

Salgın sonrası eğitim biçimi tercihi ile çalışma duru$\mathrm{mu}$ arasında da anlamlı bir ilişki bulunmuştur $(\chi 2=$ 45,704; p=0,001). Çalışmayan öğrencilerin çoğu (\%52) yüz yüze eğitimi tercih ederken (tam zamanlı çalışanların \%24'ü, yarı zamanlı çalışanların \%30'u), hibrit eğitim en fazla (\%61) yarı zamanlı çalışanlar tarafından tercih edilmektedir (çalışmayanlarda \%40, tam zamanlı çalışanlarda \%51). Uzaktan eğitimi tercih oranının en yüksek (\%25) olduğu grup tam zamanlı çalışanlardır.

Salgın sonrası eğitim biçimi tercihi ile programın ilgili olduğu alan arasında anlamlı bir ilişki bulunmuştur $(\chi 2=9,758 ; p=0,04)$. Hibrit eğitimi en yüksek oranda tercih edenler (\%62) sağlık bilimleri öğrencileridir. Yüz yüze eğitimi en çok tercih edenler (\%37) sosyal bilimler öğrencileri iken, uzaktan eğitimin tercih edilme oranı fen bilimleri alanında en yüksektir (\%25).

Salgın sonrası eğitim biçimi tercihi YL program türü ile ilişkili bulunmuştur ( $\chi 2=12,355 ; \mathrm{p}=0,02)$. Tezli ve tezsiz program öğrencilerinde hibrit eğitimi tercih edenlerin oranı en yüksek ve birbirine yakın iken; tezli programlardaki öğrencilerde yüz yüze eğitime eğilim, tezsiz programlardaki öğrencilerde uzaktan eğitime eğilim daha yüksektir. Yüz yüze eğitimi tercih edenler tezli program ögrencilerinin \%37'si, tezsiz program öğrencilerinin \%27'si iken; uzaktan eğitimi tercih edenler tezli program öğrencilerinin $\% 15^{\prime} i$, tezsiz program öğrencilerinin \%27'sidir.

Şekil 24'te görüleceği gibi, öğrencilerin \%70'i mezuniyetleri sonrasında iş hayatında, YL eğitiminin yüz yüze ya da uzaktan yapılmasının bir fark yaratmayacağını düşünmektedir. İş hayatında YL eğitimi değerlendirilirken yüz yüze eğitimin tercih edileceğini düşünenlerin oranı \%24'tür.

Mezuniyet sonrasında iş hayatına hakim olacak yaklaşım konusundaki görüşlerle program türü arasında anlamlı ilişki bulunmuştur ( $\chi 2=11,287 ; p=0,004)$. Tezsiz YL programlarındaki öğrencilerde eğitimin yüz yüze ya da uzaktan yapılmış olmasının fark yaratmayacağını düşünenler (\%75) daha büyük bir kitleyi oluşturmakta; hatta \%11'i uzaktan eğitimin makbul olacağını düşünmektedir. Tezli YL programlarındaki öğrencilerinde fark oluşmayacağını düşünenlerin oranı \%68; uzaktan eğitimin tercih edileceğini düşünenler sadece $\% 5^{\prime}$ tir.

Şekil 24. Mezuniyet Sonrası Eğitim Biçimi Tercihi

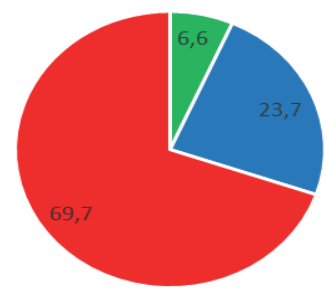

- Yüksek lisans eğitiminin uzaktan yapılmıs olması tercih sebebi olacak

- Yüksek lisans eğitiminin yüz yüze yapılmış olması tercih sebebi olacak

- Yüksek lisans eğitiminin yüz yüze ya da uzaktan yapılmış olması fark yaratmayacak 
YL öğrencilerinin COVID-19 salgını sürecindeki eğitim deneyimlerini değerlendirmek amacıyla çok say1da likert ölçekli soru yöneltilmiştir. Faktör Analizi ile incelenmesi planlanan 29 soruya öncelikle Güvenilirlik Analizi uygulanmış; Cronbach Alpha değeri 0,776 bulunmuştur. Bulunan değer, bu soruları kapsayacak ölçeğin oldukça yüksek güvenilirliğe sahip olduğunun göstergesidir.

501 gözlem ve 29 değişken için KMO değerinin 0,91 çıkması, verinin Faktör Analizi için uygunluk durumunun mükemmel olduğu şeklinde yorumlanabilir. Tablo 4'te sunulduğu üzere, Bartlett Küresellik testi sonucu da istatistiksel olarak anlamlı bulunmuştur. Bu durumda, değişkenlerin Faktör Analizi'ne elverişli bir bağımlılık yapısına sahip olduğu söylenebilir.
Uzaktan eğitim deneyimlerine dair yukarıda belirtilen 29 soru ile yapilan analiz sonucunda, boyutun $6{ }^{\prime}$ ya indirgenmesi uygun bulunmuştur. Özdeğerleri esas alan yamaç grafiği Şekil 25'te verilmiştir.

Faktörlerin toplam varyans açılama gücü \%63,932 olarak elde edilmiştir. Tablo 6' da sunulduğu gibi, Varimax döndürme sonucunda, (tarafımızca da beklendiği üzere) "sosyallik ve iletişim faktörü"; en yüksek varyans açıklama yüzdesine $(\% 14,98)$ sahip boyut olarak ortaya çıkmıştır. Daha sonra sırasıyla; "öğrencinin uzaktan öğrenme becerisi faktörü" (\%14,78), "mobil eğitimin sunduğu avantajlar faktörü" (\%10,30), “öğretim elemanlarına erişim faktörü" $(\% 8,81)$, “üniversitenin uzaktan eğitime dair teknik hizmetleri faktörü" $(\% 8,29)$ ve "uzaktan eğitimde sınav performansı faktörü" $(\% 6,77)$ tanımlanmıştır.

Tablo 4. KMO Ölçütü ve Bartlett Testi

\begin{tabular}{|c|c|c|}
\hline \multicolumn{2}{|c|}{ Kaiser-Meyer-Olkin Measure of Sampling Adequacy. } & ,910 \\
\hline Bartlett's Test of Sphericity & $\begin{array}{l}\text { Approx. Chi-Square } \\
\text { df } \\
\text { Sig. }\end{array}$ & $\begin{array}{l}8211,894 \\
406 \\
, 000\end{array}$ \\
\hline
\end{tabular}

Tablo 5. Kümünalite Değerleri

\begin{tabular}{|c|c|}
\hline & Kümünalite \\
\hline Uzaktan eğitimde mekan kısıtının olmaması avantaj sağlar & 670 \\
\hline Uzaktan eğitimde zaman kısıtının olmaması avantaj sağlar & 697 \\
\hline Uzaktan eğitimde derse devam zorunluluğu istenmemesi bir avantaj &, 538 \\
\hline Uzaktan eğitimde dijital materyallerin kullanımını, eğitimin etkinliğini arttırmaktadır &, 560 \\
\hline Uzaktan eğitimde ders kayıtlarının tekrar izlenebilmesi, başarı durumumu olumlu yönde etkilemiştir &, 522 \\
\hline Uzaktan eğitim, kampüs imkânlarından yararlanmamı kısıtladı & ,446 \\
\hline Uzaktan eğitim, öğrenciler arasındaki iletişim yönünden yüz yüze eğitime göre dezavantajlı & 677 \\
\hline Uzaktan eğitim, öğeetim üyesi-öğrenci iletişimi yönünden yüz yüze eğitime göre dezavantajlı & ,773 \\
\hline Uzaktan eğitim, öğrencilerin derse aktif katılımı yönünden yüz yüze eğitime göre dezavantajlı & ,684 \\
\hline Uzaktan eğitim, öğretim üyelerinin ders anlatma performansını olumsuz etkiliyor & 673 \\
\hline Uzaktan eğitim, öğretim üyelerinin ders anlatma motivasyonunu olumsuz etkiliyor & 699 \\
\hline Uzaktan eğitim, dersin öğretim üyesinden geri bildirim alma yönünden yüz yüze eğitime göre dezavantajlı & ,663 \\
\hline Uzaktan eğitimde dersle ilgili sorularımı öğretim üyesine iletebiliyorum & ,715 \\
\hline Yüksek lisans eğitimimle ilgili soru ve sorunlarım için yetkili öğretim elemanına ulaşabiliyorum & ,718 \\
\hline Öğretim elemanlarının uzaktan öğretimde teknoloji kullanım becerileri beklentimi karşılıyor & ,644 \\
\hline Uzaktan eğitimde ders dinlerken not tutabiliyorum & ,454 \\
\hline Dersleri rahatsız edilmeden takip edebileceğim bir ortama sahibim & ,456 \\
\hline Dersleri dinledikten sonra, düzenli olarak tekrar ya da pekiştirme çalışması yapıyorum &, 560 \\
\hline Uzaktan eğitim sisteminde, verimli biçimde ders çalışabiliyorum & ,703 \\
\hline Uzaktan eğitim kendi başıma öğrenme becerimi arttırdı & ,633 \\
\hline Uzaktan eğitim bana kendi hızımda öğrenme imkanı sağladı & 685 \\
\hline Uzaktan eğitim, öğrenmeyi öğretir & ,712 \\
\hline Uzaktan eğitim, farklı öğrenme stillerine sahip öğrenciler için avantaj sağlar & ,612 \\
\hline Öğrenci işleriyle ilgili konularda (kayıt, öğrenci belgesi) üniversitemden yeterli desteği alabildim &, 598 \\
\hline Üniversitemin uzaktan eğitim için teknolojik olarak yeterli alt yapıya sahip olduğunu düşünüyorum & ,776 \\
\hline Uzaktan eğitim sürecinde üniversitem teknik sorunları hızlı bir şekilde çözmüştür & ,808 \\
\hline Uzaktan eğitimde sınavlarda ders materyalinin açık olması bana avantaj sağladı & 489 \\
\hline Uzaktan eğitimde sınavlarda daha başarılı olduğumu düşünüyorum & 675 \\
\hline Uzaktan eğitimde başarılı olma kaygım, yüz yüze eğitimden daha az & ,701 \\
\hline
\end{tabular}




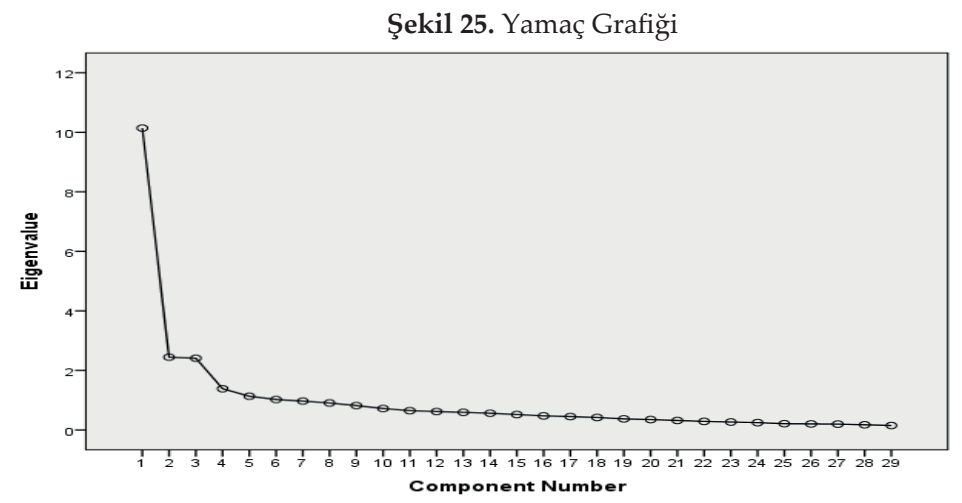

Tablo 6. Faktörler

\begin{tabular}{c|l|r|r}
\multicolumn{2}{l|}{ Faktör } & Özdeğer & Varyans \% \\
\hline 1 & Sosyallik ve İletişim & 4,343 & 14,98 \\
\hline 2 & Uzaktan Öğrenme Becerisi & 4,286 & 14,78 \\
\hline 3 & Eğitimin Mobilitesi & 2,988 & 10,30 \\
\hline 4 & Hocalara Erişim & 2,554 & 8,81 \\
\hline 5 & Kurumun Teknik Hizmetleri & 2,405 & 8,29 \\
\hline 6 & Uzaktan Sinav & 1,965 & 6,77 \\
\hline & & & $\mathbf{6 3 , 9 3 2}$
\end{tabular}

Birinci faktör; hem öğrenciler hem de öğrenciler ile öğretim üyeleri arasındaki iletişim ve sosyalleşme kısıtlarını, öğretim üyelerinin uzaktan ders verme becerilerini kapsamaktadır. İkinci faktör; öğrencilerin bireysel uzaktan öğrenme becerilerini kapsamaktadır. Üçüncü faktör, uzaktan eğitimin zaman ve mekandan bağımsız olması ve dijital ders materyali, kayıt imkanı gibi olanakların etkilerini içermektedir. Dördüncü faktör, ders ve diğer konularda ilgili öğretim elemanına ulaşılabilirlikle ilgili hususları; beşinci faktör, üniversitenin uzaktan eğitim ile ilgili teknik hizmetleri ile ilgili deneyimleri kapsamaktadır. Altıncı faktör ise uzaktan eğitimde sınav uygulamalarına dair görüşleri içerir. İlgili faktör yükleri Tablo 7'de sunulmuştur.

Cinsiyete göre faktör skorlarının hiç biri yönünden is-

Tablo 7. Faktör Yükleri Matrisi

\begin{tabular}{|c|c|c|c|c|c|c|}
\hline & \multicolumn{6}{|c|}{ Faktör } \\
\hline & $\begin{array}{c}1 \\
\text { Sosyallik } \\
\text { ve İletişim }\end{array}$ & $\begin{array}{c}2 \\
\text { Uzaktan } \\
\text { Öğrenme } \\
\text { Becerisi }\end{array}$ & $\begin{array}{c}3 \\
\text { Eğitimin } \\
\text { Mobilitesi }\end{array}$ & $\begin{array}{c}4 \\
\text { Hocalara } \\
\text { Erişim }\end{array}$ & $\begin{array}{c}5 \\
\text { Kurumun } \\
\text { Teknik } \\
\text { Hizmetleri }\end{array}$ & $\begin{array}{c}6 \\
\text { Uzaktan } \\
\text { Sinav }\end{array}$ \\
\hline U. eğitim, kampüs imkânlarından yararlanmamı kısıtladı &, 591 &,- 214 &,- 025 & ,161 &,- 148 &,- 050 \\
\hline U. eğitim, öğrenciler arasındaki iletişim yönünden YY eğitime göre dezavantajlı & ,786 &,- 145 &,- 150 & 083 &,- 085 & ,038 \\
\hline U. eğitim, öğr. elemanı-öğrenci iletişimi yönünden YY eğitime göre dezavantajlı & 846 &,- 135 &,- 131 &, 000 &,- 144 &,- 009 \\
\hline U. eğitim, öğrencilerin derse aktif katılımında YY eğitime göre dezavantajlı & ,747 &,- 218 &,- 173 &,- 194 &,- 004 &,- 108 \\
\hline U. eğitim, ögretim üyelerinin ders anlatma performansını olumsuz etkiliyor & ,649 &,- 187 &,- 069 &,- 417 &,- 005 &,- 196 \\
\hline U. eğitim, öğretim üyelerinin ders anlatma motivasyonunu olumsuz etkiliyor & 665 &,- 128 &,- 054 &,- 439 & 053 &,- 204 \\
\hline U. eğitim, öğr. elemanından geri bildirim almada YY eğitime göre dezavantajlı & 684 &,- 256 &,- 142 &,- 293 &,- 149 &, 034 \\
\hline U. eğitimde dersle ilgili sorularımı öğretim elemanına iletebiliyorum &,- 155 & 251 & ,236 & ,727 & 208 &, 000 \\
\hline YL eğitimimle ilgili soru ve sorunlarım için öğretim elemanına ulaşabiliyorum &,- 066 & 235 & 095 & ,764 &, 255 & 028 \\
\hline Öğr. elemanlarının U. öğretimde teknoloji kul. becerileri beklentimi karşılıyor &,- 078 &, 178 &, 116 & ,678 & ,354 & ,088 \\
\hline U. eğitimde ders dinlerken not tutabiliyorum &,- 144 &, 572 &, 144 & ,263 & 021 &, 127 \\
\hline Dersleri rahatsız edilmeden takip edebileceğim bir ortama sahibim &,- 046 &, 593 &, 184 &, 181 &, 170 & , 086 \\
\hline Dersleri dinledikten sonra, düzenli olarak tekrar pekiștirme çalışması yapıyorum &,- 199 & ,681 &,- 054 & 089 & 074 & ,201 \\
\hline U. eğitim sisteminde, verimli biçimde ders çalışabiliyorum &,- 369 & ,639 &, 191 & ,156 &, 114 & ,291 \\
\hline U. eğitim kendi başıma öğrenme becerimi arttırdı &,- 223 & ,676 & 308 &, 140 &,- 031 & , 107 \\
\hline U. eğitim bana kendi hızımda öğrenme imkanı sağladı &,- 268 & ,687 &, 335 &, 130 & 034 & 108 \\
\hline U. eğitim, öğrenmeyi öğretir &,- 368 & ,672 &, 320 & 056 & 084 &, 111 \\
\hline U. eğitim, farklı öğrenme stillerine sahip öğrenciler için avantaj sağlar &,- 257 &, 569 & ,446 & 093 & ,099 & 070 \\
\hline U. eğitimde mekan kısıtının olmaması avantaj sağlar &,- 268 & ,264 & ,722 & ,068 &,- 015 &, 042 \\
\hline U. eğitimde zaman kısıtının olmaması avantaj sağlar &,- 227 & ,303 & ,728 &, 052 &, 109 & 095 \\
\hline U. eğitimde derse devam zorunluluğu istenmemesi bir avantaj &,- 035 & 059 & ,703 &, 107 &, 053 &, 156 \\
\hline U. eğitimde dijital materyallerin kullanımını, eğitimin etkinliğini arttırmaktadır &,- 146 & ,352 &, 502 & ,298 &,- 069 & ,262 \\
\hline U. eğitimde ders kayıtlarının tekrar izlenmesi, başarımı olumlu yönde etkiledi & ,007 & ,325 &, 545 &, 154 &,- 002 &, 310 \\
\hline Öğrenci işleriyle ilgili konularda üniversitemden yeterli desteği alabildim &,- 102 & , 080 & ,084 & ,245 & ,717 &,- 012 \\
\hline Üniversitemin U. eğitim için yeterli alt yapıya sahip olduğunu düşünüyorum &,- 124 & ,083 &,- 001 &, 112 &, 843 &, 176 \\
\hline U. eğitim sürecinde üniversitem teknik sorunları hızlı bir şekilde çözmüştür &,- 104 & 068 & ,004 &, 181 &, 863 &, 122 \\
\hline U. eğitimde sınavlarda ders materyalinin açık olması bana avantaj sağladı & ,051 & 350 &, 197 & ,198 &, 109 &, 523 \\
\hline U. eğitimde sınavlarda daha başarılı olduğumu düşünüyorum &,- 122 & 295 & ,222 &, 034 &, 134 & ,711 \\
\hline U. eğitimde başarılı olma kaygım, YY eğitimden daha az &,- 114 &, 103 &, 143 &,- 023 & ,106 & 803 \\
\hline
\end{tabular}


tatistiksel olarak anlamlı bir fark bulunamamıştır. Bu durumda, araştırmanın başında öne sürülen hipotezin aksine, YL öğrencilerinin uzaktan eğitim deneyimlerinde cinsiyetin fark yaratan etkili bir faktör olmadığ söylenebilir.

Yaş gruplarına göre uygulanan Welch testi sonucunda, "sosyallik ve iletişim faktörü" ( $p=0,039)$, "uzaktan öğrenme becerisi faktörü" ( $p=0,001)$, “hocalara erişim faktörü" ( $p=0,026)$ ve "uzaktan sinav faktörü" yönünden $(p=0,036)$ istatistiksel olarak anlamlı fark bulunmuştur.

Şekil 26'da verilen grafiklerde görüldüğü gibi, “sosyallik ve iletişim faktörü" yönünden 23-27 yaş grubu diğer yaş gruplarından farklılaşmaktadır. En genç grubun, öğrenciler arasındaki ve öğrenciler ile öğretim elemanları arasındaki iletişimi daha fazla öncelediği söylenebilir.
Uzaktan öğrenme becerisi ve hocalara erişim faktörleri yönünden 33+ yaş grubu, daha küçük yaş gruplarından farklılaşmaktadır. Üst yaş grubundaki öğrencilerin bu konulardaki beceri ve esnekliklerinde nisbi bir düşüş olduğu söylenebilir.

Sınav performansı yönünden ise tüm gruplar arasında anlamlı farklılık gözlenmektedir. Yaş arttıkça uzaktan sinav uygulamasına adaptasyon azalmaktadir.

Medeni durum bazında incelendiğinde, $\mathrm{t}$ testi sonucuna göre "sosyallik ve iletişim faktörü" $(p=0,002)$, "uzaktan öğrenme becerisi faktörü" $(p=0,015)$, "hocalara erişim faktörü" $(p=0,038)$ ve "uzaktan sinav faktörü" yönünden ( $p=0,023)$, evli ve bekar öğrenciler arasında anlamlı fark bulunmuştur.

Bir işte çalışan öğrenciler ile çalışmayanlar arasında t testi sonucuna göre "sosyallik ve iletişim faktörü" $(p=0,003)$, "eğitimin mobilitesi faktörü" $(p=0,001)$ ve

Şekil 26. Yaş Kategorileri - Faktörler

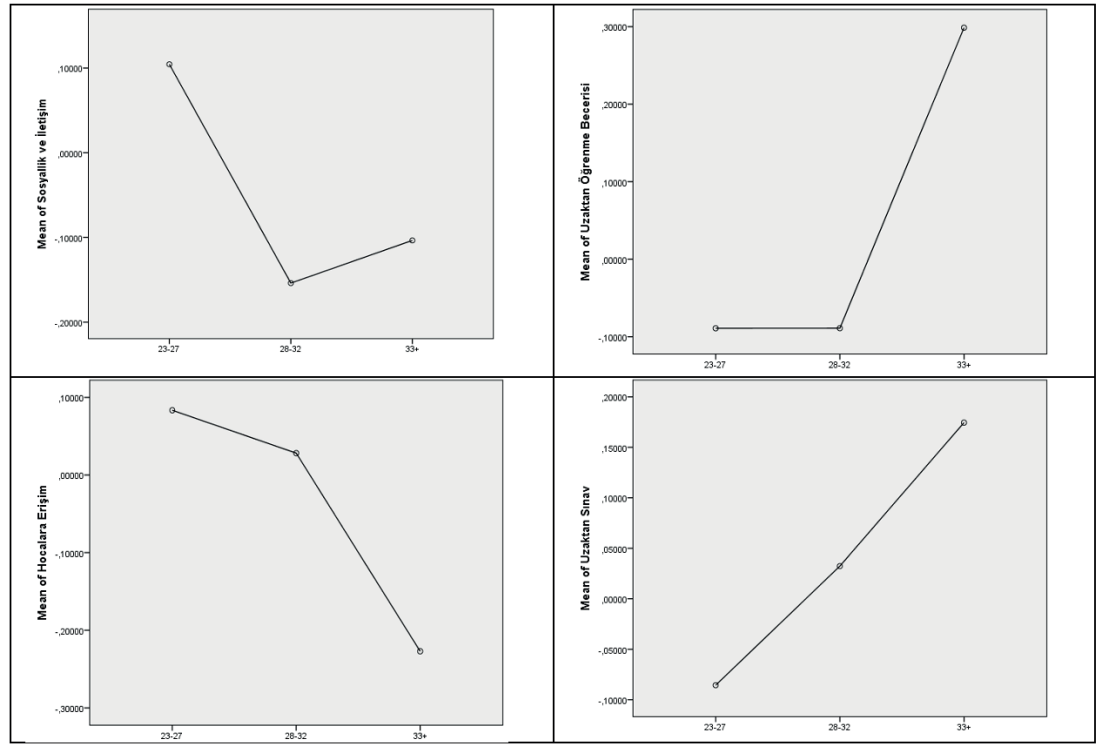

Şekil 27. YL Program - Hocalara Erişim Faktörü

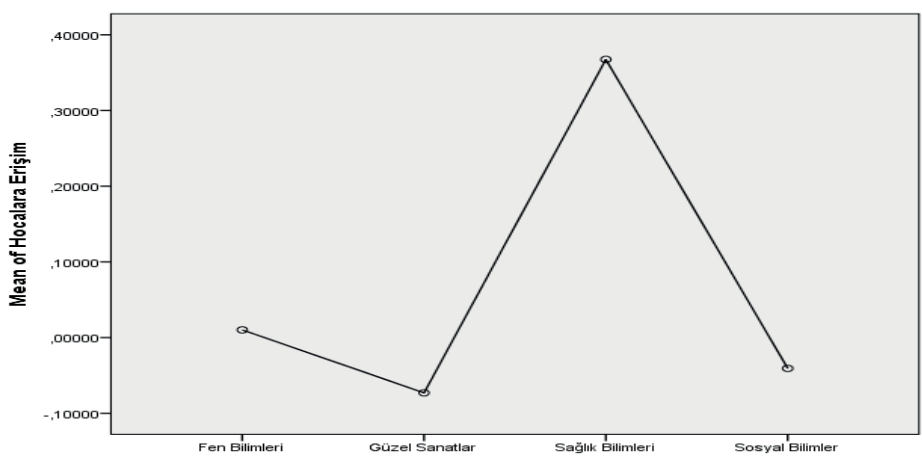


"uzaktan sinav faktörü" yönünden $(\mathrm{p}=0,047)$ anlamlı fark tespit edilmiştir.

YL program türüne göre (tezli/tezsiz) bakıldığında, t testi sonucuna göre "uzaktan eğitim becerisi faktörü" $(\mathrm{p}=0,005)$, “eğitimin mobilitesi faktörü" $(\mathrm{p}=0,0001)$, "hocalara erişim faktörü" $(p=0,046)$, "uzaktan sinav faktörü" yönünden $(p=0,002)$ anlamlı fark tespit edilmiştir. Tezsiz YL öğrencilerinde uzaktan eğitimi tercih eğilimi daha yüksek, eğitimin mobil olması ve sınavların uzaktan yapılması da daha fazla memnuniyet vermektedir.

YL programının alanı bazında yapılan Welch testi sonuçlarına göre, "hocalara erişim faktörü" yönünden $(p=0,045)$ anlamlı bir fark bulunmuştur. Şekil27' de verildiği gibi, sağlık bilimleri öğrencileri ile diğer alanlardaki öğrenciler arasında anlamlı bir fark bulunmuştur. Sağlık bilimleri öğrencileri, hocalara erişim sorunu yaşamadıklarını ifade etmektedirler.

\section{SONUÇ}

COVID-19 salgınının gerektirdiği uzaktan eğitim sürecinin, YL öğrencilerinin perspektifi ile ele alındığ 1 bu çalışmada, online anket aracılığıyla öğrencilerden derlenen veriler tanımlayıcı ve çıkarımsal istatistikler aracılığıyla analiz edilmiştir. Araştırmanın temel bulgularından biri, eğitimin uzaktan uygulanmasının YL yapma talebini arttıran bir faktör olduğudur. Salgın sürecinin özellikle tezsiz YL yapan öğrenciler tarafından bir eğitim fırsatı olarak görüldüğü anlaşılmaktadır. YL programının ilgili olduğu alan yönünden bakıldığında ise, uzaktan eğitim uygulanacağı için YL yapma kararı alanların ağırlığı fen bilimleri alanında en yüksek bulunmuştur. Bu sonuçların, tezsiz YL yapan ve fen bilimleri alanında YL yapan öğrenciler arasında tam zamanlı bir işte çalışanların ağırlığının yüksek olmasından kaynaklandığı düşünülmüştür.

Genel olarak öğrencilerin çoğunun salgın öncesinde herhangi bir uzaktan eğitim deneyimine sahip olmadığı, bununla birlikte uzaktan eğitim sistemine adapte olma konusunda yaygın bir sıkıntı yaşanmadığı anlaşılmıştır. Uzaktan eğitimde ders ve sınav sistemine adaptasyon becerisinin yaş ile negatif korelasyonlu olduğu da tespit edilmiştir.

Kullanılan teknolojiye bakıldığında, uzaktan eğitim platformları arasında Zoom lider konumdadır. Öğrencilerin tamamına yakını, kişisel bilgisayarı ile derse bağlanmayı tercih etmektedir. Ayrıca; öğrencilerin ders ya da sınav sırasında kişisel internet bağlantılarının kalitesi konusunda önemli ölçüde sorun yaşadığı da tespit edilmiştir.

Öğrencilerin, aldıkları YL eğitiminden oldukça memnun olduğu ve bu memnuniyetin oluşmasında "öğretim elemanlarının yetkinliğinin" en önemli etken olduğu anlaşılmaktadır. Öğrencilerin uzaktan eğitim deneyimlerine dair öne çıkan en önemli iki görüş; “uzaktan eğitimin öğrenciler arasındaki iletişimi sekteye uğratması yönünden dezavantajı" ile "ders kayıtlarının tekrar tekrar izlenebilmesi konusundaki avantajidır".

Uzaktan eğitime ilişkin görüşler esas alınarak yapılan Faktör Analizi ile altı alt boyut tanımlanmıştır. Elde edilen boyutlar önem sırasıyla; "sosyallik ve iletişim", "öğrencilerin uzaktan öğrenme becerisi", "mobil eğitimin sunduğu avantajlar", "öğretim elemanlarına erişim", "üniversitenin uzaktan eğitime dair teknik hizmetleri" ve "uzaktan eğitimde sınav performansı" olarak isimlendirilmiştir.

YL öğrencilerinin uzaktan eğitim deneyimlerindeki farklılıklarda cinsiyet etkili bir faktör değildir. Medeni durum, bir işte çalışma durumu ve yaş ise etkili faktörler olarak tespit edilmiştir. Evli öğrencilerin çoğu bir işte çalışan ve ileri yaş grubundaki öğrenciler olup, uzaktan eğitimi ve uzaktan sinavı tercih etmekte; bir işte çalışmayan öğrencilerin çoğu bekar ve alt yaş grubunda olup, uzaktan eğitimin yol açtı̆̆ iletişim kısıtları bu grup için rahatsız edici unsurlar olarak daha fazla vurgulanmıştır.

Öğrencilerin çoğu yüz yüze eğitimi daha verimli bulmakla birlikte; uygulama derslerinin ağırlığı ile yüz yüze eğitimi tercih etme oranı arasında pozitif bir korelasyon söz konusudur.

Ani bir biçimde hayatımıza giren uzaktan eğitimin öğrenciler tarafından çok çabuk benimsendiği; öğrencilerin yarısının, salgın süreci sona erdiğinde hibrit (yüz yüze+uzaktan) eğitimi tercih edeceği anlaşılmaktadır. Bununla birlikte tezli programlardaki öğrencilerde yüz yüze eğitime eğilim, tezsiz programlardaki öğrencilerde uzaktan eğitime eğilim daha yüksek bulunmuştur. Alan bazında incelendiğinde, yüz yüze eğitimi en çok tercih edenler sosyal bilimler öğrencileri iken, uzaktan eğitimi en çok tercih edenler fen bilimleri öğrencileridir.

Öğrencilerin çoğu mezuniyetleri sonrasında iş ha- 
yatında, YL eğitiminin yüz yüze ya da uzaktan yapılmasının bir fark yaratmayacağını; sadece $1 / 4^{\prime} \ddot{u}$ iş hayatında YL eğitimini yüz yüze yapanların tercih edileceğini düşünmektedir.

Salgın sürecinde edinilen deneyimler, hem yöneticiler hem de öğretim elemanları nezdinde gelecekte benimsenecek eğitim-öğretim stratejileri konusunda bir revizyona ihtiyaç olduğu gerçeğini gün yüzüne çıkarmıştır. Bu çalışmada elde edilen bulguların, mevcut ya da yeni YL programlarının kapsam, içerik ve metodolojik yönden yapılandırılmasında yol gösterici nitelikte olduğu düşünülmektedir. Demografik segmentler bazında öğrencilerin uzaktan eğitime yatkınlıklarının tespiti, yeni uzaktan eğitim programları için hedef kitlenin belirlenmesi, teknik alt yapı ihtiyacının tanımlanması, etkin öğrenme için yeni ders ve sınav metotlarının araştırılması vb. bağlamda bu çalışmanın sonuçlarından yararlanılabilir.

İzleyen çalışmalarda lisans, yüksek lisans ve doktora düzeylerinde eş zamanlı araştırmalar yapılarak, uzaktan eğitim konusunda öğrenci görüşlerinin karşılaşt1rılmasının önemli bulgular ortaya koyacağ mektedir. Ayrıca; uzaktan eğitim konusunda öğretim elemanlarının ve kurum yöneticilerinin görüşlerine başvurulan çalışmalara da ihtiyaç olduğu belirtilmelidir.

\section{KAYNAKÇA}

ABREU, A., COSTA, E., \& PAIVA, J. (2021). Distance Learning in Higher Education during the COVID-19 pandemic: A Systematic Literature Review. . Research Bulletin (Cadernos de Investigação) of the Master in E-Business.

ADNAN, M., \& ANWAR, K. (2020). Online Learning amid the COVID-19 Pandemic: Students' Perspectives. . Online Submission 2(1), 45-51.

ALPAR, R. (2013). Uygulamalı Çok Değişkenli İstatistiksel Yöntemler. Ankara: Detay Yayıncılık.

APPOLlONI, A., COLASANTI, N., FANTAUZZI, C., FIORANI, G., \& FRONDIZI, R. (2021). Distance Learning as a Resilience Strategy during Covid-19: An Analysis of the Italian Context. Sustainibility, https:// doi. org $/ 10.3390 /$ su13031388.

ARIK, S. (2021). Distance Education Learning Environments During COVID-19 Pandemic from Student Perspectives: A Study in Turkish Higher Education. Journal of Pedagogical Research, 103-118.

ARAR, T., ÖNEREN, M., \& YURDAKUL, G. (2021). Covid-19 Kapsamında Uzaktan Eğitim Sürecinin Lisansüstü Öğrencilerin Algısındaki Yeri: Kırıkkale Üniversitesi Örneği. Üniversite Araștırmaları Dergisi, 154-167.

BENZER, S., \& AKKAYA, M. M. (2021). Pandemi Sürecinde Fen Bilimleri Alanında Uzaktan Eğitim. Sosyal Bilimler Elektronik Dergisi, 19-46.
CHURIYAH, M., SHOLIKHAN, S., FILIANTI, F., \& SAKDIYYAH, D. (2020). Indonesia Education Readiness Conducting Distance Learning in Covid-19 Pandemic Situation. International Journal of Multicultural and Multireligious Understanding, 491-508.

DIDENKO, I., FILATOVA, O., \& ANISIMOVA, L. (2021, Ocak). Covid-19 Lockdown Challenges or New Era for Higher Education. https://revistas.usil. edu.pe/index.php/pyr/article/view/914 adresinden alındı

ERDEM AYDIN, İ. (2021). Öğrencilerin Acil Uzaktan Öğretim Uygulamas1na İlişkin Görüş ve Önerilerinin Ekolojik Sistem Bağlamında Değerlendirilmesi. Açıköğretim Uygulamaları ve Araștırmaları Dergisi, 35-64.

GENÇ, S. Z., ENGIN, G., \& YARDIM, T. (2020). Pandemi (COVID19) Sürecindeki Uzaktan Eğitim Uygulamalarına İlişkin Lisansüstü Öğrenci Görüşleri. Atatürk Üniversitesi Kazım Karabekir Eğitim Fakültesi Dergisi, 134-158.

HAIR, J., BLACK, W., BABIN, B., \& ANDERSON, R. (2010). Multivariate Data Analysis: A Global Perspective. New Jersey: Pearson.

JADHAV, V., BAGUL, T., \& ASWALE, S. (2020). COVID-19 Era: Students ' Role to Look at Problems in Education System during Lockdown Issues in Maharashtra, India . International Journal of Research \& Review (IJRR), 327-332.

KAUR, G. (2020). Digital Life: Boon or Bane in Teaching Sector on COVID-19. CLIO an Annual Interdisciplinary Journal of History, 416-427.

MACH, L., \& PONTING, J. (2021). Establishing a pre-COVID-19 Baseline for Surf Tourism: Trip Expenditure and Attitudes, Behaviors and Willingness to Pay for Sustainability. Annals of Tourism Research Empirical Insights.

ROSINSKA, E., \& ZHURAVSKA, O. (2021, Ocak). Satisfaction with Distant Learning and end - of - Course Productivity Research Gate: https:// www.researchgate.net/publication/350917822_SATISFACTION_WITH DISTANT_LEARNING_AND_END-OF-COURSE_PRODUCTIVITY adresinden alınd 1

SALTA, K., PASCHALIDOU, K., \& TSETSERI, M. (2021). Shift From a Traditional to a Distance Learning Environment during the COVID-19 Pandemic. Science \& Education.

TÜZÜN, F., \& YÖRÜK TOROMAN, N. (2020). COVID19 Sürecinde Uzaktan Eğitim Öğrenci Memnuniyetini Etkileyen Faktörlerin SEK Yöntemi ile Analizi. International Conference on Distance Learning and Innovative Educational Technologies (s. 302-317). Ankara: Başkent Üniversitesi Uzaktan Eğitim Uygulama ve Araştırma Merkezi.

TADESSE, S., \& MULUYE, W. (2020). The Impact of COVID-19 Pandemic on Education System in Developing Countries: A Review. Open Journal of Social Science, https://www.scirp.org/journal/paperinformation.aspx?paperid $=103646$

THOMAS, C. (2020). Coronavirus and Challenging Times for Education in Developing Countries. Washington DC: The Brookings Institution.

TOTI, G., \& ALIPOUR, M. A. (2021). Computer Science Students' Perceptions of Emergency Remote Teaching: An Experience Report . SN Computer Science, 370-378.

UNESCO. (2020). Distance Learning Solutions. UNESCO. https://en.unesco.org/covid19/educationresponse/solutions. adresinden alındı

VEGAS, E. (2020). School Closures, Government Responses, and Learning Inequality around the World during COVID-19. Washington DC: The Brookings Institution, https://www.brookings.edu/research/school-closures-government-responses-and-learning-inequality-around-the-world-during-covid-19/. 